\title{
Neonatal sepsis and its associated factors in East Africa: a systematic review and meta-analysis, 2019
}

Biruk Beletew ( $\sim$ birukkelemb@bmc.com )

Woldia University

Ayelign Kassie

Woldia University

Mesfin Wudu kassaw

Woldia University

Mikias Amare Getu

Woldia University

Research article

Keywords: Neonatal sepsis, Eastern Africa

Posted Date: August 30th, 2019

DOI: https://doi.org/10.21203/rs.2.13740/v1

License: @ (i) This work is licensed under a Creative Commons Attribution 4.0 International License.

Read Full License 


\section{Abstract}

Background: Neonatal sepsis is one of the most leading causes of inflated death and illness of neonates. Different primary studies in Eastern Africa showed the burden of neonatal sepsis. However, inconsistency among those studies was seen and no review has been conducted to report the amalgamated magnitude and associated factors. Therefore, this review aimed to estimate the national prevalence and associated factors of neonatal sepsis in Eastern Africa.

Methods: Using PRISMA guideline, we systematically reviewed and meta-analyzed studies that examined the prevalence and associated factors of neonatal sepsis from PubMed, Cochrane library, and Google Scholar. Heterogeneity across the studies was evaluated using the $\mathrm{Q}$ and the $\mathrm{I} 2 \mathrm{test}$. A weighted inverse variance random-effects model was applied to estimate the national prevalence and the effect size of associated factors. The subgroup analysis was conducted by country, study design, and year of publication. A funnel plot and Egger's regression test were used to see publication bias.

Result: A total of 26 studies with 11239 participants were used for analysis. The pooled prevalence of neonatal sepsis in East Africa was 29.65\% (95\% Cl; 23.36-35.94). Home delivery(AOR $=2.67 ; 95 \%$ Cl: 1.15 $4.00 ; 12=0.0 \% ; P=0.996)$, maternal history of UTI (AOR=2.083; 95\% Cl :0.24-3.93; I2=69.1\%; $\mathrm{P}=0.001)$, gestational age (preterm) $(\mathrm{AOR}=1.56 ; 95 \% \mathrm{Cl}: 1.04-2.08 ; \mathrm{I} 2=27.8 \% ; \mathrm{P}=0.000)$, prolonged labor $(A O R=3.23 ; 95 \% \mathrm{Cl}:-0.04-6.51 ; \mathrm{I} 2=62.7 \% ; \mathrm{P}=0.020)$ and $\mathrm{PROM}(\mathrm{AOR}=1.95 ; 95 \% \mathrm{Cl}: 0.53-3.37 ; \mathrm{I} 2=43.2 \%$; $\mathrm{P}=0.062$ ) were identified factors of neonatal sepsis.

Conclusions: The prevalence of neonatal sepsis in Eastern Africa remains high. This review may help policy-makers and program officers to design neonatal sepsis preventive interventions. Keywords: Neonatal sepsis, Eastern Africa

\section{Background}

Neonatal sepsis is a systemic infection occurring in neonatal life and is a major cause of morbidity and mortality in newborns (1). It is categorized as early-onset neonatal sepsis (EONS) and late-onset neonatal sepsis (LONS) based on the onset of clinical features (2). EONS is sepsis occurring within seven days of life after birth and LONS is sepsis from after the seventh day of life(3). Neonatal sepsis contributes considerably to neonatal morbidity and mortality and is an continuing major global public health challenge(4). As documented in different literatures, neonatal sepsis is caused by factors related to both maternal and neonatal factors such as prolonged rupture of membrane (PROM),, urinary tract infection, intrapartum fever, instrumental delivery,prematurity, chorioamnionitis, frequent vaginal examination, never attend antenatal care (ANC), home delivery, meconium-stained amniotic fluid, contaminated foods intake, low birth weight, complicated or instrument-assisted delivery, low appearance pulse grimace activity respiration (APGAR) scores and invasive procedures during hospital admission (5-11). Guidelines for the treatment of neonatal sepsis have been formulated and its implementation along with timely initiation of better treatments would satisfactorily decrease morbidity and mortality of neonates by sepsis(3). 
Identification of the risk factors for risk-based diagnosis of neonatal sepsis contributes to better interventions and studies that help to reduce the burden of neonatal mortality resulting from these risks.

Worldwide, neonatal infections cause estimated $26 \%$ of under -5 deaths, with mortality rates highest in sub-Saharan Africa (4). Globally, sepsis in neonates is still among the principal causes of neonatal mortality and morbidity, especially in the first seven days of life in low and middle-income countries (LMIC) $(12,13)$.

About four million worldwide deaths in neonates per year, from this $98 \%$ is from developing countries particularly in sub-Saharan Africa(14). The risk of neonatal death is estimated to be six times more in the low and middle-income countries compared to developed (15). Timely diagnosis is difficult due to its nonspecific clinical manifestations. Besides, treating neonates with antibiotics merely by subtle manifestations is likely to over-treat non-infected neonates(16). The ideal approach will be detecting highrisk neonates and steering them for intensive therapy (17).

Incidence of neonatal sepsis is about forty times higher and mortality rates are two times higher in middle-income countries compared with high-income countries(18).

Neonatal sepsis poses a massive public health burden for sub-Saharan Africa with significant associated economic consequences(19).In Africa sepsis accounts $28 \%$ neonatal deaths and infectious causes account for 68 deaths per 1000 live births(7).In sub-Saharan Africa, seventeen percent among all neonatal death results from neonatal sepsis as compared to only six percent in developed countries(20).

NS is also one of the most common cause of neonatal death in East Africa; it is the cause for more than one-third of neonatal deaths in Ethiopia particularly (21).

To achieve sustainable development goal (SDG) reducing newborn and under-five mortality as low as $12 / 1000$ and 25/1000 respectively is one of the Global strategies of WHO in African countries by 2030 . This could be achieved through better prevention and management of preterm births and severe infections as the key (22).

Identification of risk factors and timely initiation of treatments can significantly decrease neonatal mortality and morbidity (23).

In the last two decades, remarkable progress has been shown on maternal and child deaths, but neonatal health is a part of the 'unfinished agenda'. The world is experiencing an increase in the proportion of under-five death occurring in the neonatal period. Yet despite the neonatal deaths are preventable, they are concentrated in the world's poorest countries. And $85 \%$ of all the neonatal were occurred in low and middle-income countries (LMICs) even though they are home to only $62 \%$ of the world's newborns $(6,24)$.

Indeed, strategies that can prevent and treat neonates with sepsis are essential to accelerate the progress of newborn survival. In many developing country settings, however, the identification and treatment of 
newborns with infection is unsatisfactory. Identification of risk factors and early institution of therapy thereby can improve neonatal mortality and morbidity $(6,25)$.

In East Africa, a variety of studies was conducted to estimate the prevalence of neonatal sepsis. However, the prevalence of neonatal sepsis ranges from 4.7\%\% [Amare Gebrehiwot et al(25)] to 77.9\% (James A. Berkley et al.)(26)which showed great inconsistencies across different geographical settings and different periods. Besides, there are some contradicting or inconsistent findings on risk factors and mortality predictors of neonatal sepsis. Besides, there is no regionally represented pooled data of neonatal sepsis in East Africa. Therefore, this systematic review and meta-analysis were aimed, firstly, to estimate the pooled prevalence of neonatal sepsis and secondly, to estimate the effect size of associated factors of neonatal sepsis in East Africa context.

\section{Methods}

\section{Reporting}

The results of this review were reported based on the Preferred Reporting Items for Systematic Review and Meta-Analysis statement (PRISMA) guideline (Supplementary file-PRISMA checklist) and, it is registered in the Prospero database: (PROSPERO 2019: CRD42019130792) Available from https: // www. Crd.york. ac. UK/ PROSPERO_REBRANDING/ display_record. asp ID = CRD42019130792

\section{Searching strategy and information sources}

PubMed, Google Scholar, and Cochrane library were accessed. Articles with incomplete reported data were handled through contacting corresponding authors.

The core search terms and phrases were "neonate", "newborn", "infant", and "sepsis"," septicemia "," infection", "Eastern Africa”. The search strategies were developed using different Boolean operators. Notably, to fit advanced PubMed database, the following search strategy was applied: (prevalence OR magnitude) AND (causes OR determinants OR associated factors OR predictors)AND (newborn [MeSH Terms] OR neonate OR infant OR child OR children)AND (sepsis [MeSH Terms] OR septicemia OR infection)AND (Eastern Africa). We also screened at the reference lists of the remaining papers to identify additional relevant studies to this review.

\section{Study selection / Eligibility criteria}

Retrieved studies were exported to reference manager software, Endnote version 8 to remove duplicate studies. Two investigators (BB and AM) independently screened the identified studies using their titles and abstracts before retrieval of full-text papers. We used pre-specified inclusion criteria to further screen the full-text articles. Disagreements were discoursed during a consensus meeting with a third reviewer (MW) for the final selection of studies to be included in the systematic review and meta-analysis. 


\section{Inclusion and exclusion criteria}

This systematic review and meta-analysis included Cross-sectional, case-control, and cohort studies. Those studies had reported the prevalence and/or at least one associated factors of neonatal sepsis and published in English language were considered. There was no restriction of the researches study period. Citations lacking abstract and/or full-text, anonymous reports, editorials, and qualitative studies were excluded from the analysis.

\section{Quality assessment}

The qualities of the studies were appraised by three independent authors. The Joanna Briggs Institute (JBI) quality appraisal checklist was used (27). The disagreement was resolved by the interference of the third reviewer. The following items were used to appraise cohort studies: (1) similarity of groups, (2) similarity of exposure measurement, (3) validity and reliability of measurement, (4) identification of confounder,(5) strategies to deal with confounder, (6) appropriateness of groups/participants at the start of the study,(7) validity and reliability of outcome measured, (8) sufficiency of follow-up time, (9) completeness of follow-up or descriptions of reason to loss to follow-up, (10) strategies to address incomplete follow-up, and (11) appropriateness of statistical analysis. The items used to appraise casecontrol studies were: (1) comparable groups, (2) appropriateness of cases and controls, (3) criteria to identify cases and controls, (4) standard measurement of exposure, (5) similarity in measurement of exposure for cases and controls, (6) handling of confounder (7), strategies to handle confounder, (8) standard assessment of outcome, (9) appropriateness of duration for exposure, and (10) appropriateness of statistical analysis. Studies got $50 \%$ and above of the quality scale were considered low risk. The following items were used to appraise cross-sectional studies: (1) inclusion criteria, (2) description of study subject and setting, (3) valid and reliable measurement of exposure, (4) objective and standard criteria used,(5)identification of confounder, (6) strategies to handle confounder, (7) outcome measurement, and (8)appropriate statistical analysis. Studies were considered low risk when it scored $50 \%$ and above of the quality assessment indicators.

Data extraction

Two independent reviewers extracted data using a structured data extraction form. Whenever variations of extracted data observed, the phrase was repeated. If discrepancies between data extractors continued, the third reviewer was involved. The name of the first author and year, the study country, the study design, the target population, the sample size, prevalence of neonatal sepsis, and AOR of associated factors were collected.

\section{Outcome measurement}

Neonatal sepsis was considered, neonates with presence of at least one clinical sign plus at least two laboratory results which are suggestive for neonatal sepsis (CRP,WBC,ANC, ESR, Platelet count, and Blood 
glucose) or neonates who are diagnosed as sepsis by attending physician and fulfill sepsis criteria within $0-28$ days of life

\section{Statistical analysis}

We pooled the overall prevalence estimates of neonatal sepsis by a random effect meta-analysis

(28).We examined the heterogeneity of effect size using Q statistic and the $I^{2}$ statistics(28). The Q-test measures whether the observed effect size is considerably different from one another than expected by chance. When $\mathrm{Q}$ test is higher than the degree of freedom it indicates significant heterogeneity (also supplemented by P-value). The 12 statistics assess the proportion of total variance across the included studies contributed to the observed heterogeneity. In this study, the I 2 statistic value of zero indicates true homogeneity, whereas the value 25,50 , and $75 \%$ represented low, moderate and high heterogeneity respectively $(29,30)$.

For the data identified as heterogeneous, we conducted our analysis by random-effects model analysis.

When statistical pooling is not possible, non-pooled data was presented in table form.

Subgroup analysis was done by the study country, design, and year of publication. Sensitivity analysis was employed to see the effect of a single study on the overall estimation.

Publication bias was checked by funnel plot and more objectively through Egger's regression test (31).

\section{Result}

\section{Study selection}

A total of 4931 studies were identified; 3282 from PubMed, 12 from Cochrane Library, 1610 from Google Scholar and 27 from other sources. After duplication removed, 1235 remained. Finally, 301 studies were screened for full-text review and finally, $26(n=11,239)$ were selected for the prevalence and/ or associated factors analysis (Fig. 1).

\section{Characteristics of included studies}

26 papers were included in this systematic review and meta-analysis [32-36]

10 studies were found in Ethiopia [Alebachew(32), Yirga T.et al./ 2018(33), Gebrehiwot et al/2012(25), G/eyesus et al /2017(5), Gebremedhin et al /2016(6), Getabelew et al. /2017(34), Shitaye D et al/2010(35), Yusuf et al/2008(36), Abate et al/2016(5), Mersha et al. /2019(37) ], 
7 in Kenya [Kwame et al/2011(38),MUMBI S. et al /2010(39),Mulongo N et al/2018(40),A.M.R. LAVING et al./ 2003(41),Alison W A et al/2012(42),J LeGeyt et al./ 2016(43),James A. et al./ 2005(44) ], 3 in Sudan [Abdelmoneim E. M et al./ 2014(45),Wafa Babiker et al./ 2018(46),Abd Elrahman et al/2018(47) ], and 6 in Uganda [Petwa(48), K.W. et al./ 2015,J Mugalu et al./ 2006(49),N. A. Mobbs et al/2019(50), Kiwanuka J et al/2013(51),Okaba et al /2018(52), Bua John et al/2015(44) ]. 19 of the studies were done by cross-sectional study design, three studies by case-control study design, whereas four of the studies were conducted through cohort study design respectively. Regarding the year of publication, 4 studies were published between 2000 and 2010, and 22 studies were between 2010 and 2017. The studies included participants, ranging from 62 (32) to 4849 (James
A.) (Table 1).

\section{Characteristics and quality status of the studies}

Table 1: Distribution of studies on the prevalence and determinants of neonatal sepsis in Ethiopia 


\begin{tabular}{|c|c|c|c|c|c|}
\hline Author & $\begin{array}{l}\text { Study } \\
\text { country }\end{array}$ & $\begin{array}{l}\text { Study } \\
\text { design }\end{array}$ & $\begin{array}{l}\text { Sample } \\
\text { size }\end{array}$ & $\begin{array}{l}\text { Prevalence } \\
(\%)\end{array}$ & $\begin{array}{l}\text { Quality } \\
\text { status }\end{array}$ \\
\hline Alebachew et al/2014(32) & Ethiopia & $\begin{array}{l}\text { cross- } \\
\text { sectional }\end{array}$ & 306 & - & Low risk \\
\hline Yirga T.et al./ 2018(33) & Ethiopia & $\begin{array}{l}\text { case- } \\
\text { control }\end{array}$ & 231 & - & Low risk \\
\hline Gebrehiwot et al/2012(25) & Ethiopia & $\begin{array}{l}\text { cross- } \\
\text { sectional }\end{array}$ & 181 & 32.10 & Low risk \\
\hline $\begin{array}{l}\text { G/eyesus et al / } 2017 \text { et al. } \\
\text { (5) }\end{array}$ & Ethiopia & $\begin{array}{l}\text { cross- } \\
\text { sectional }\end{array}$ & 251 & 0.466 & Low risk \\
\hline $\begin{array}{l}\text { Gebremedhin et al } \\
/ 2016(6)\end{array}$ & Ethiopia & $\begin{array}{l}\text { case- } \\
\text { control }\end{array}$ & 232 & & Low risk \\
\hline Getabelew et al. /2017(34) & Ethiopia & $\begin{array}{l}\text { cross- } \\
\text { sectional }\end{array}$ & 244 & 77.90 & Low risk \\
\hline Shitaye D et al/2010(35) & Ethiopia & $\begin{array}{l}\text { cross- } \\
\text { sectional }\end{array}$ & 302 & 44.70 & Low risk \\
\hline Yusuf et al/2008(36) & Ethiopia & $\begin{array}{l}\text { cross- } \\
\text { sectional }\end{array}$ & 578 & 28.70 & Low risk \\
\hline Abate et al/2016(5) & Ethiopia & cohort & 1189 & 4.70 & Low risk \\
\hline ). Mersha et al. /2019(37) & Ethiopia & $\begin{array}{l}\text { cross- } \\
\text { sectional }\end{array}$ & 275 & 33.80 & Low risk \\
\hline $\begin{array}{l}\text {.. Petwa, K.W. et al./ } \\
\text { 2015(48) }\end{array}$ & Uganda & $\begin{array}{l}\text { cross- } \\
\text { sectional }\end{array}$ & 258 & 24.00 & Low risk \\
\hline ¿. J Mugalu et al./ 2006(49) & Uganda & $\begin{array}{l}\text { cross- } \\
\text { sectional }\end{array}$ & 290 & 37.90 & Low risk \\
\hline $\begin{array}{l}\text { N. N. Aobbs et } \\
\text { al/2019(50) }\end{array}$ & Uganda & cohort & 103 & 30.30 & Low risk \\
\hline t. Kiwanuka J et al/2013(51) & Uganda & $\begin{array}{l}\text { cross- } \\
\text { sectional }\end{array}$ & 80 & 32.50 & Low risk \\
\hline i. Okaba et al /2018(52) & Uganda & cohort & 325 & 11 & Low risk \\
\hline i. Kwame et al/2011(38) & Kenya & $\begin{array}{l}\text { case- } \\
\text { control }\end{array}$ & 100 & - & Low risk \\
\hline '. MUMBI S. et al /2010(39) & Kenya & $\begin{array}{l}\text { cross- } \\
\text { sectional }\end{array}$ & 104 & - & Low risk \\
\hline 3. Mulongo $\mathrm{N}$ et al/2018(40) & Kenya & $\begin{array}{l}\text { cross- } \\
\text { sectional }\end{array}$ & 256 & 13.29 & Low risk \\
\hline $\begin{array}{l}\text { I. A.M.R. LAVING et al./ } \\
\text { 2003(41) }\end{array}$ & Kenya & $\begin{array}{l}\text { cross- } \\
\text { sectional }\end{array}$ & 84 & 17.90 & Low risk \\
\hline I. Alison W A et al/2012(42) & Kenya & cross- & 4,849 & 23.00 & Low risk \\
\hline
\end{tabular}


sectional

\begin{tabular}{|c|c|c|c|c|c|}
\hline .. J LeGeyt et al./ 2016(43) & Kenya & Cohort & 1262 & 23.90 & Low risk \\
\hline ¿. James A. et al./ 2005(44) & Kenya & $\begin{array}{l}\text { cross- } \\
\text { sectional }\end{array}$ & 1783 & 12.80 & Low risk \\
\hline 3. Bua John et al/2015(44) & Uganda & $\begin{array}{l}\text { cross- } \\
\text { sectional }\end{array}$ & 174 & 21.80 & Low risk \\
\hline $\begin{array}{l}\text { t. Abdelmoneim E. M et al./ } \\
\text { 2014(45) }\end{array}$ & Sudan & $\begin{array}{l}\text { cross- } \\
\text { sectional }\end{array}$ & 62 & 17.50 & Low risk \\
\hline $\begin{array}{l}\text { i. Wafa Babiker et al./ } \\
\text { 2018(46) }\end{array}$ & Sudan & $\begin{array}{l}\text { cross- } \\
\text { sectional }\end{array}$ & 119 & 37.80 & Low risk \\
\hline $\begin{array}{l}\text { i. Abdulrahman et } \\
\text { al/2018(47) }\end{array}$ & Sudan & $\begin{array}{l}\text { cross- } \\
\text { sectional }\end{array}$ & 200 & 62 & Low risk \\
\hline
\end{tabular}

\section{Quality of studies}

The JBI quality appraisal criteria established for cross-sectional, case-control, and cohort studies were used. The studies included in this systematic review and meta-analysis had no considerable risk. Therefore, all the studies were considered [2, 6-7, 33-52] (Table1).

\section{Meta-analysis}

Prevalence of neonatal sepsis

21 studies [Abate et al(5), Okaba et al(52) ,James A. ,Bua John(44), Mulongo N (40),Abdelmoneim E. ,A.M.R. LAVING ,Alison W A (42),J LeGeyt (43),Petwa(48), Yusuf et al(36), N. A. Mobbs (50), Gebrehiwot(25),Kiwanuka J (51), Mersha et al. (37),Wafa ,Babiker ,J Mugalu(49) ,Shitaye D(35) , G/eyesus(5),AbdElrahman, Getabelew(34) ] revealed the prevalence of neonatal sepsis .The prevalence ranges from $4.7 \%$ (Abate et al(5)) up to $77.9 \%$ (Getabelew et al (34)). From those studies, the pooled prevalence of neonatal sepsis in East Africa was 29.65 \% (95\%CI; 23.36-35.94). We found significant heterogeneity among the studies $\left(\mathrm{I}^{2}=98.8 \%\right.$; $\left.<0.001\right)$. We analyzed by random-effects model analysis and we did subgroup analysis (Figure 2).

Test of heterogeneity

Subgroup analysis of the prevalence of neonatal sepsis in Eastern Africa 
The subgroup analysis was done based on the country, study design, and year of publication. Based on this, the prevalence of neonatal sepsis found to be $38.31 \%$ in Ethiopia, 24.4\% in Uganda, 18.28\% in Kenya, and 39.26.Based on design $32.63 \%$ in crosssectional studies and $17.08 \%$ in cohort studies. Based on the year of publication $23.05 \%$ from 2000-2010, 33.01\% from 2010-2015 and 31.39 from 2015-2019(Table 2 and Figure 3, 4 and 5).

\begin{tabular}{llll}
\hline Variables & Characteristics & Pooled prevalence $(95 \%$ CI) & $\mathrm{I}^{2}$ (P-value) \\
\hline By country & Ethiopia & $38.31(17.43-59.19)$ & $99.5 \%(<0.001)$ \\
& Uganda & $24.4(14.91-33.90)$ & $93.9 \%(<0.001)$ \\
Kenya & $18.28(12.64-23.91)$ & $96.9 \%(<0.001)$ \\
By design & Sudan & $39.26(13.31-65.22)$ & $96.6 \%(<0.001)$ \\
& Cross-sectional & $32.63(25.53-39.73)$ & $98.4 \%(<0.001)$ \\
By year of publication $)$ & Cohort & $17.08(5.22-28.95)$ & $98.7 \%(<0.001)$ \\
& $2000-2010$ & $23.05(12.38-33.73)$ & $96.7 \%(<0.001)$ \\
& $2010-2015$ & $33.01(20.62-45.40)$ & $96.5 \%(<0.001)$ \\
& $2015-2019$ & $31.39(19.68-43.10)$ & $99.1 \%(<0.001)$ \\
\hline
\end{tabular}

\section{Sensitivity analysis}

We employed a leave-one-out sensitivity analysis to identify the potential source of heterogeneity in the analysis of the prevalence of neonatal sepsis in Eastern Africa. The results of this sensitivity analysis showed that our findings were not dependent on a single study. Our pooled estimated prevalence of neonatal sepsis varied between 27.15(21.6832.61) and 30.94(24.96-36.92) after deletion of a single study.

Abd Elrahman et al/2018(47), Abate et al/2016 (5), Gebremedhin et al /2016 (6), Getabelew et al. /2017(34) had shown an impact on the overall estimation(Figure 6).

\section{Publication bias}

A funnel plot showed asymmetrical distribution .Egger's regression test p-value was 0.010, which indicated the presence of publication bias. 


\section{Prevalence of neonatal sepsis}

The estimated overall prevalence of neonatal sepsis is presented in a forest plot (Fig. 4). The overall prevalence of LBW was 29.65\% (95\% CI; 23.36-35.94; $\mathrm{I}^{2}=98.8 \%$ ) (Figure 7).

\section{Factors associated with neonatal sepsis}

In Eastern Africa context neonatal sepsis is associated with socio-economic, obstetric and maternal behavior, infant, and environmental-related factors (Table 3).

\section{Table 3: Factors associated with neonatal sepsis}




\begin{tabular}{|c|c|c|c|}
\hline Factors & Odds ratio (AOR) & Author & Year \\
\hline \multirow[t]{5}{*}{ Place of birth } & 4.20 & Alebachew et al. & 2014 \\
\hline & 4.36 & Yirga et al. & 2018 \\
\hline & 6.36 & G/eyesus et al. & 2017 \\
\hline & 19.00 & Gebremedhin et al. & 2016 \\
\hline & 6.00 & Getabelew et al. & 2017 \\
\hline \multirow[t]{9}{*}{ Maternal history of UTI } & 2.9 & Alebachew et al. & 2014 \\
\hline & 10.8 & Yirga et al. & 2018 \\
\hline & 7.06 & G/eyesus et al. & 2017 \\
\hline & 15.04 & Gebremedhin et al. & 2016 \\
\hline & 6.45 & Getabelew et al. & 2017 \\
\hline & 6.28 & Okaba et al. & 2018 \\
\hline & 3.37 & Bua John et al. & 2015 \\
\hline & 1.65 & J Mugalu et al. & 2006 \\
\hline & 1.12 & Mersha et al. & 2019 \\
\hline \multirow[t]{10}{*}{ Gestational age(preterm) } & 6.44 & Alebachew et al. & 2014 \\
\hline & 3.49 & Yirga et al. & 2018 \\
\hline & 10.60 & G/eyesus et al. & 2017 \\
\hline & 38.60 & Gebremedhin et al. & 2016 \\
\hline & 7.38 & Getabelew et al. & 2017 \\
\hline & 2.92 & Yusuf et al. & 2008 \\
\hline & 1.49 & Abate et al. & 2016 \\
\hline & 4.66 & J LeGeyt et al. & 2016 \\
\hline & 7.22 & Mulongo $\mathrm{N}$ et al & 2018 \\
\hline & 6.45 & A.M.R. LAVING et al. & 2003 \\
\hline \multirow[t]{6}{*}{ Prolonged labor } & 6.95 & Alebachew et al. & 2014 \\
\hline & 11.92 & Yirga et al. & 2018 \\
\hline & 1.29 & G/eyesus et al. & 2017 \\
\hline & 1.41 & J Mugalu et al. & 2006 \\
\hline & 2.53 & Getabelew et al. & 2017 \\
\hline & 12.4 & Okaba et al. & 2018 \\
\hline \multirow[t]{10}{*}{ PROM } & 5.20 & A.M.R. LAVING et al. & 2003 \\
\hline & 10.37 & Yirga et al. & 2018 \\
\hline & 11.80 & G/eyesus et al. & 2017 \\
\hline & 27.10 & Gebremedhin et al. & 2016 \\
\hline & 1.28 & Getabelew et al. & 2017 \\
\hline & 1.85 & Mersha et al. & 2019 \\
\hline & 1.56 & $\mathrm{~J}$ Mugalu et al. & 2006 \\
\hline & 4.74 & Okaba et al. & 2018 \\
\hline & 6.7 & MUMBI S. et al. & 2010 \\
\hline & 8.28 & Mulongo $\mathrm{N}$ et al. & 2018 \\
\hline
\end{tabular}

\section{Place of birth}

Five studies (Alebachew et al (32), Yirga (33), Gebremedhin(6)) found a significant association between home delivery and neonatal sepsis. Alebachew et al revealed that the odds of neonatal sepsis was higher among newborns who delivered at home (AOR=4.2, $95 \%$ CI: 1.93, 8.97) compared to those who delivered at the health institution. Yirga et al revealed that neonates who delivered at home were 4.36 times at risk of being neonatal 
sepsis compared to those who delivered at the health institution. G/eyesus et al(5) revealed that neonates who delivered at home were 6.36 times at risk of being neonatal sepsis compared to those who delivered at the health institution. Gebremedhin et al(6) found that the odds of neonatal sepsis was higher among newborns who delivered at home (AOR=19, 95\% CI: $1.74,4.41)$ compared to those who delivered at the health institution. Getabelew et al revealed that neonates who delivered at home were 6 times at risk of being neonatal sepsis compared to those who delivered at the health institution. Four studies (Mersha et al., J Mugalu, Okaba, et al, Bua John et al) found no significant association between place of birth and neonatal sepsis.

\section{Test of heterogeneity place of birth}

Galbraith plot showed homogeneity and combining the result of nine studies the forest plot showed the overall estimate of AOR of home delivery was 2.67( 95\%C I: 1.15-4.00; $\mathrm{I}^{2}=$ $0.0 \% ; \mathrm{P}=0.996) . \mathrm{I}$-Squared $\left(\mathrm{I}^{2}\right)$ and $\mathrm{P}$-value also showed homogeneity.

\section{Publication bias place of birth}

A funnel plot showed an asymmetrical distribution. Egger's regression test p-value was 0.003, which indicated the presence of publication bias.

\section{Trim and fill analysis place of birth}

Trim and fill analysis was done and 4 studies were added and the total number of studies become 13 .the pooled estimate of AOR of home delivery becomes 2.36(Figure 8).

The pooled effect of place of birth

\section{Publication bias for the place of birth}

The Beggs test shows there is publication bias regarding place of birth(Figure 9)

\section{Trim and fill analysis place of birth}

After adding 4 studies during trim and fill the effect size of place of birth changed from 2.57 to2,36(Figure 10).

\section{Maternal history of UTI}


Seven studies (Alebachew(32), Yirga(33), G/eyesus et al(5), Gebremedhin(6), Getabelew et al(34), Okaba et al(52) and Bua John et al(44) found a significant association between maternal history of and neonatal sepsis.

Alebachew et al revealed that the odds of neonatal sepsis was higher among neonates whose mother have a history of UTI(AOR=2.9,95\% CI: 1.48, 5.52) compared to those whose mother has no history of UTI. Yirga et al revealed that neonates whose mother have a history of UTI were 10.8 times at risk of being neonatal sepsis (95\% CI: 3.44, 33.97) compared to those who delivered at the health institution. G/eyesus et al revealed that neonates whose mothers have a history of UTI were 7.06 times at risk of being neonatal sepsis compared to those whose mother has no history of UTI. Gebremedhin et al (6)found that the odds of neonatal sepsis was higher among neonates whose mother have a history of UTI (AOR=15.04, 95\% CI: 1.65, 3.38) compared to those whose mother has no history of UTI. Getabelew et al revealed that neonates whose mothers have a history of UTI were 6.45 times at risk of being neonatal sepsis compared to those whose mother has no history of UTI. Okaba et al revealed that the odds of neonatal sepsis was higher among neonates whose mother have a history of UTI (AOR=6.28, 95\% CI: $1.62,7.38$ ) compared to those whose mother has no history of UTI. Bua John et al revealed that the odds of neonatal sepsis was higher among neonates whose mother have a history of UTI (AOR=3.37,95\% CI: $1.23,9.22$ ) compared to those whose mother has no history of UTI. Four studies (J Mugalu, Mersha, et al.) found no significant association between maternal history of UTI and neonatal sepsis.

\section{Test of heterogeneity for the maternal history of UTI}

Galbraith plot showed moderate heterogeneity and the forest plot showed the overall estimate of AOR of a place of birth was 2.083( $95 \%$ C I: $0.24-3.93 ; \mathrm{I}^{2}=69.1 \% ; \mathrm{P}=0.001$ ). ISquared $\left(\mathrm{I}^{2}\right)$ and P-value also showed substantial heterogeneity. Main meta-analysis was done with random effect models(Figure 11).

The pooled estimate of UTI

\section{Publication bias maternal history of UTI}

A funnel plot showed a symmetrical distribution. Egger's regression test p-value was 0.928, which indicated the absence of publication bias(Figure 12).

Eight studies (Alebachew(32), Yirga(33), G/eyesus et al(5), Gebremedhin, Getabelew et al(34), Yusuf et al(36), Abate et al(5) ,J LeGeyt et al. (43)) found significant association between gestational age and neonatal sepsis. Alebachew et al revealed that preterm 
neonates were 6.44 times at risk of being neonatal sepsis compared to term neonates. Yirga et al revealed that preterm neonates were 3.49 times at risk of being neonatal sepsis (95\% CI: $1.14,10.67)$ compared to term neonates. G/eyesus et al revealed that preterm neonates were 10.6 times at risk of being neonatal sepsis compared to term neonates. Gebremedhin et al found that the odds of neonatal sepsis was higher among preterm neonates (AOR=38.6, 95\% CI: 1.96, 9.51) compared to term neonates. Getabelew et al revealed that preterm neonates were 7.38 times at risk of being neonatal sepsis compared to term neonates. Yusuf et al revealed that the odds of neonatal sepsis was higher among preterm neonates (AOR=2.92, 95\% CI: 1.97, 4.31) compared to term neonates. Abate et al revealed that preterm neonates were 1.49 times at risk of being neonatal sepsis compared to term neonates. J LeGeyt et al. found that the odds of neonatal sepsis was higher among preterm neonates (AOR=4.66, 95\% CI: 0.65,0.98) compared to term neonates. Two studies (Mulongo $\mathrm{N}$ et al, A.M.R. LAVING et al., found no significant association between gestational age and neonatal sepsis.

\section{Test of heterogeneity gestational age}

Galbraith plot showed moderate heterogeneity and the forest plot showed the overall estimate of AOR of the place of birth was 1.56 (95\% CI: 1.04-2.08; I ${ }^{2}=27.8 \%$; P=0.000). ISquared $\left(\mathrm{I}^{2}\right)$ and $\mathrm{P}$-value also showed moderate heterogeneity.

\section{Publication bias gestational age}

A funnel plot showed an asymmetrical distribution. Egger's regression test p-value was 0.000 , which indicated the presence of publication bias.

\section{Trim and fill analysis gestational age}

Trim and fill analysis was done and 2 studies were added and the total number of studies become 12 .the pooled estimate of AOR of preterm becomes 4.69(Figure 13).

Preterm pooled estimate

Publication bias preterm

Begg's test shows there is publication bias among studies regarding gestational age of respondents (Figure 14). 
Trim and fill

After trim and fill analysis two studies were added and the pooled effect size changed from 1.56 to 4.69 (Figure 15).

\section{Prolonged labor}

Four studies (Alebachew(32), Yirga(33), Getabelew et al(34), Okaba et al(52) found a significant association between prolonged labor and neonatal sepsis. Alebachew et al revealed that mothers of neonates who have a history of prolonged labor were 6.95 times at risk of being neonatal sepsis compared to those who have no history of prolonged labor. Yirga et al shown that mothers of neonates who have a history of prolonged labor were 11.92 times at risk of being neonatal sepsis compared to those who have no history of prolonged labor. Getabelew et al revealed that mothers of neonates who have a history of prolonged labor were 2.53 times at risk of being neonatal sepsis compared to those who have no history of prolonged labor. Okaba et al shown that mothers of neonates who have a history of prolonged labor were 12.4 times at risk of being neonatal sepsis compared to those who have no history of prolonged labor. Two studies (G/eyesus et al, J Mugalu )found no significant association between prolonged labor and neonatal sepsis.

\section{Test of heterogeneity prolonged labor}

Galbraith plot showed moderate heterogeneity and the forest plot showed the overall estimate of AOR of the place of birth was 3.23 (95\% CI: $-0.04-6.51 ; \mathrm{I}^{2}=62.7 \%$; $\mathrm{P}=0.020$ ) .ISquared $\left(\mathrm{I}^{2}\right)$ and P-value also showed substantial heterogeneity (Figure 16).

Publication bias

\section{Publication bias prolonged labor}

A funnel plot showed a symmetrical distribution. Egger's regression test p-value was 0.770, which indicated the absence of publication bias (Figure 17).

\section{PROM}

Seven studies ( Yirga(33), G/eyesus et al(5), Gebremedhin(6), Okaba, et al, MUMBI S. et al(39), Mulongo $\mathrm{N}$ et al, A.M.R. LAVING et al.) found a significant association between PROM and neonatal sepsis. Yirga et al revealed that mothers of neonates who have history 
of PROM were 10.37 times at risk of being neonatal sepsis (95\% CI: $2.3,46.5)$ compared to those who have no history of PROM.G/eyesus et al indicated that mothers of neonates who have history of PROM were 11.8 times at risk of being neonatal sepsis compared to those who have no history of PROM. Gebremedhin et al found that mothers of neonates who have a history of PROM were 27.1 times at risk of being neonatal sepsis (95\% CI: 2.01, 6.39) compared to those who have no history of PROM. Okaba et al revealed that mothers of neonates who have a history of PROM were 4.74 times at risk of being neonatal sepsis compared to those who have no history of PROM. MUMBI S. et al indicated that mothers of neonates who have a history of PROM were 6.7 times at risk of being neonatal sepsis compared to those who have no history of PROM. Mulongo $\mathrm{N}$ et al, revealed that mothers of neonates who have history of PROM were 8.28 times at risk of being neonatal sepsis compared to those who have no history of PROM.A.M.R. LAVING et al. indicated that mothers of neonates who have history of PROM were 5.2 times at risk of being neonatal sepsis compared to those who have no history of PROM. Three studies (Getabelew, Shitaye D, et al,Mersha et al. , J Mugalu ) found no significant association between PROM and neonatal sepsis.

\section{Test of heterogeneity PROM}

Galbraith plot showed moderate heterogeneity and the forest plot showed the overall estimate of AOR of a place of birth was 1.95 (95\% CI: 0.53-3.37; $\mathrm{I}^{2}=43.2 \%$; $\mathrm{P}=0.062$ ).ISquared $\left(\mathrm{I}^{2}\right)$ and P-value also showed moderate heterogeneity(Figure 18).

Publication bias

\section{Publication bias PROM}

A funnel plot showed an asymmetrical distribution. Egger's regression test p-value was 0.030, which indicated the presence of publication bias (Figure 19).

Trim and fill PROM

\section{Trim and fill analysis PROM}

Trim and fill analysis was done and 4 studies were added and the total number of studies become 15 .The pooled estimate of AOR of preterm becomes 5.86 (Figure 20). 


\section{Discussion}

In this systematic review and meta-analysis, we explored the prevalence and determinants of neonatal sepsis in Eastern Africa. 26 studies were included in the final analysis. Based on the meta-analysis a significant proportion (more than 1 in 4) of neonates had neonatal sepsis in Eastern Africa. This shows that neonatal sepsis is a significant public health problem in Eastern Africa. We also identified factors that were significantly associated with neonatal sepsis in Eastern Africa. In this study, the pooled prevalence of neonatal sepsis in Eastern Africa was. The pooled prevalence of neonatal sepsis in East Africa was 29.65 \%( 95\%CI; 23.36-35.94).The results of this meta-analysis were higher than in studies conducted in other low and middle-income countries (LMICs), 17.2\% (53).

These differences might be due to the socioeconomic and cultural differences between the countries. Moreover, the other obvious reason for the various might be the sample size, a collection of data from different settings (community and institution setting) as well as different study periods. Home delivery, maternal history of UTI, being preterm, prolonged labor and PROM were identified factors which significantly increase the risk of neonatal sepsis. A similar finding was also reported from the meta-analysis (54-56).

\section{Conclusion}

The prevalence of neonatal sepsis in Eastern Africa remains high. Home delivery, maternal history of UTI, being preterm, prolonged labor and PROM were identified factors which significantly increase the risk of neonatal sepsis. This review may help policy-makers and program officers to design neonatal sepsis preventive interventions.

\section{Strength And Limitations}

This study has several strengths: First, we used a pre-specified protocol for search strategy and data abstraction and conducted quality assessment two independent investigators to lessen the possible assessor bias; Second, we employed subgroup and sensitivity analysis based on study country, study design, and publication year to identify the small study effect and the risk of heterogeneity in; third, The quality of the included studies was evaluated by two authors. Nevertheless, our systematic review and meta-analysis have some limitations: The result in this meta-analysis is derived from studies conducted in hospital settings. This limits the generalizability of the review findings.

\section{Recommendations}

\section{For health workers}


Professionals who are working in NICUs should adhere to aseptic techniques while carrying out neonatal invasive procedures. And attention should be given for neonates delivered from women with intranasal fever to prevent neonatal sepsis. Pregnant women should be screened for UTI and those diagnosed with urinary tract infection should be treated with a full course of antibiotics for the prevention of neonatal sepsis.

\section{For mothers}

Women who didn't have complete ANC services, should get all their antenatal care schedules according to Ethiopian Ministry of Health (EMH) and take prompt action in seeking medical help during obstetric emergencies including rupture of membrane before labor.

\section{For the Ministry of health and health service organizations}

The government should increase the political priority given to sepsis by improving awareness of the growing medical and economic burden of neonatal sepsis. Primary care organizations should increase 36 their support towards maternal education and incorporate routine neonatal sepsis screening into the care of neonates and mothers.

\section{For researchers}

Researchers who are interested to conduct on neonatal sepsis should have to include neonates in the community which may increase the external validity of the study.

\section{Abbreviations}

EONS: early-onset neonatal sepsis; LONS: late-onset neonatal sepsis ; PROM: prolonged rupture of membrane ;UTI: Urinary Tract Infection; OR: Odds Ratio; UNICEF: The United Nations Children's Fund; WHO: World Health Organization; Cl: Confidence interval; DHS: Demographic and Health Surveys; EDHS: Ethiopian Demographic and Health Survey

\section{Declarations}

\section{Ethics approval and consent to participate}

Not applicable because no primary data were collected

\section{Consent for publication}

Note applicable.

\section{Availability of data and materials}

Data is available and it can be accessed from the corresponding author when asked with a reasonable inquiry. 


\section{Competing interests}

The authors declare that they have no competing interests.

\section{Funding}

None

\section{Authors' contributions}

BB conceives and designed the study. AM, MW and MA established the search strategy. All authors read the manuscript before they have given the final approval for publication and approved the submission of the paper.

\section{Acknowledgments}

Not applicable

\section{Authors' information}

All Authors are permanent workers at Woldia University, Faculty of Health Sciences, and Department of Nursing: P.O. Box 400, Woldia, Ethiopia.

\section{References}

1. Simonsen KA, Anderson-Berry AL, Delair SF, Davies HD. Early-onset neonatal sepsis. Clinical microbiology reviews. 2014;27(1):21-47.

2. Cizmeci MN, Kara S, Kanburoglu MK, Simavli S, Duvan Cl, Tatli MM. Detection of cord blood hepcidin levels as a biomarker for early-onset neonatal sepsis. Medical hypotheses. 2014;82(3):310-2.

3. Adhikari NK, Fowler RA, Bhagwanjee S, Rubenfeld GD. Critical care and the global burden of critical illness in adults. The Lancet. 2010;376(9749):1339-46.

4. Aijaz N, Huda N, Kausar S. Disease burden of NICU, at a tertiary care hospital, Karachi. Journal of Dow University of Health Sciences. 2013;6(1).

5. Moges F, Eshetie S, Yeshitela B, Abate E. Bacterial etiologic agents causing neonatal sepsis and associated risk factors in Gondar, Northwest Ethiopia. BMC pediatrics. 2017;17(1):137.

6. Gebremedhin D, Berhe H, Gebrekirstos K. Risk factors for neonatal sepsis in public hospitals of Mekelle City, North Ethiopia, 2015: unmatched case control study. PloS one. 2016;11(5):e0154798.

7. Tewabe T, Mohammed S, Tilahun Y, Melaku B, Fenta M, Dagnaw T, et al. Clinical outcome and risk factors of neonatal sepsis among neonates in Felege Hiwot referral Hospital, Bahir Dar, Amhara Regional State, North West Ethiopia 2016: a retrospective chart review. BMC research notes. 2017;10(1):265.

8. Leal YA, Álvarez-Nemegyei J, Velázquez JR, Rosado-Quiab U, Diego-Rodríguez N, Paz-Baeza E, et al. Risk factors and prognosis for neonatal sepsis in southeastern Mexico: analysis of a four-year historic cohort follow-up. BMC pregnancy and childbirth. 2012;12(1):48.

9. Wang ME, Patel AB, Hansen NI, Arlington L, Prakash A, Hibberd PL. Risk factors for possible serious bacterial infection in a rural cohort of young infants in central India. BMC public health. 2016;16(1):1097. 
10. Santhanam S, Arun S, Rebekah G, Ponmudi NJ, Chandran J, Jose R, et al. Perinatal Risk Factors for Neonatal Early-onset Group B Streptococcal Sepsis after Initiation of Risk-based Maternal Intrapartum Antibiotic Prophylaxis-A Case Control Study. Journal of tropical pediatrics. 2017;64(4):312-6.

11. John B DM, Mathias L, Elizabeth N:. Risk factors and practices contributing to newborn sepsis in a rural district of Eastern Uganda, August 2013: a cross sectional study. BMC research notes 2015, 8:339.

12. Seale AC, Blencowe H, Manu AA, Nair H, Bahl R, Qazi SA, et al. Estimates of possible severe bacterial infection in neonates in sub-Saharan Africa, south Asia, and Latin America for 2012: a systematic review and meta-analysis. The Lancet infectious diseases. 2014;14(8):731-41.

13. Liu L, Oza S, Hogan D, Chu Y, Perin J, Zhu J, et al. Global, regional, and national causes of under-5 mortality in 2000-15: an updated systematic analysis with implications for the Sustainable Development Goals. The Lancet. 2016;388(10063):3027-35.

14. EMOH:. Health Sector Transformation Plan(HSTP 2015/16 - 2019/20 (2008-2012 EFY) October In.; . 2015: 1-182.

15. Edmond K, Zaidi A. New approaches to preventing, diagnosing, and treating neonatal sepsis. PLoS medicine. 2010;7(3):e1000213.

16. Alkema L, New JR, Pedersen J, You D. Child mortality estimation 2013: an overview of updates in estimation methods by the United Nations Inter-agency Group for Child Mortality Estimation. PloS one. 2014;9(7):e101112.

17. EMOH:. Health Sector Transformation Plan(HSTP 2015/16 - 2019/20 (2008-2012 EFY) October In.; . 2015: 1-182.

18. Fleischmann-Struzek C, Goldfarb DM, Schlattmann P, Schlapbach LJ, Reinhart K, Kissoon N. The global burden of paediatric and neonatal sepsis: a systematic review. The Lancet Respiratory Medicine. 2018;6(3):223-30.

19. Ranjeva SL, Warf BC, Schiff SJ. Economic burden of neonatal sepsis in sub-Saharan Africa. BMJ global health. 2018;3(1):e000347.

20. Debelew GT, Afework MF, Yalew AW. Determinants and causes of neonatal mortality in Jimma zone, southwest Ethiopia: a multilevel analysis of prospective follow up study. PLoS One. 2014;9(9):e107184.

21. UNICEF:. committing to Child Survival:A Promise Renewed World Health Organ Tech Rep Ser. . 2014:1-100.

22. Organization WH. World health statistics 2016: monitoring health for the SDGs sustainable development goals: World Health Organization; 2016.

23. UNICEF:. committing to Child Survival :A Promise Renewed World Health Organ Tech Rep Ser. . 2014:1-100.

24. WHO U. Every newborn: an action plan to end preventable deaths. Geneva: World Health Organization. 2014. 
25. Gebrehiwot A, Lakew W, Moges F, Anagaw B, Yismaw G, Unakal C. Bacterial profile and drug susceptibility pattern of neonatal sepsis in Gondar University Hospital, Gondar Northwest Ethiopia. Der Pharmacia Lettre. 2012;4(6):1811-6.

26. Seale AC, Mwaniki M, Newton CR, Berkley JA. Maternal and early onset neonatal bacterial sepsis: burden and strategies for prevention in sub-Saharan Africa. The Lancet infectious diseases. 2009;9(7):428-38.

27. Peters MD, Godfrey CM, McInerney P, Soares CB, Khalil H, Parker D. The Joanna Briggs Institute reviewers' manual 2015: methodology for JBI scoping reviews. 2015.

28. Borenstein M, Hedges LV, Higgins JP, Rothstein HR. A basic introduction to fixed-effect and randomeffects models for meta-analysis. Research synthesis methods. 2010;1(2):97-111.

29. Ioannidis JP. Interpretation of tests of heterogeneity and bias in meta-analysis. Journal of evaluation in clinical practice. 2008;14(5):951-7.

30. Higgins JP, Thompson SG. Quantifying heterogeneity in a meta-analysis. Statistics in medicine. 2002;21(11):1539-58.

31. Egger M, Smith GD, Schneider M, Minder C. Bias in meta-analysis detected by a simple, graphical test. Bmj. 1997;315(7109):629-34.

32. Woldu M, Guta M, Lenjisa J, Tegegne G, Tesafye G, Dinsa H. Assessment of the incidence of neonatal sepsis, its risk factors, antimicrobial use and clinical outcomes in Bishoftu General Hospital. Neonatal Intensive Care Unit, Debrezeit-Ethiopia Pediat Therapeut. 2014;4(214):21610665.1000214 .

33. T. Y. PREDICTORS OF NEONATAL SEPSIS IN PUBLIC REFERRAL HOSPITALS OF EAST AND WEST GOJJAM ZONES OF AMHARA REGIONAL STATE, NORTH WEST ETHIOPIA: A CASE CONTROL STUDY. 2018.

34. Getabelew A, Aman M, Fantaye E, Yeheyis T. Prevalence of neonatal sepsis and associated factors among neonates in neonatal intensive care unit at selected governmental hospitals in Shashemene Town, Oromia Regional State, Ethiopia, 2017. International journal of pediatrics. 2018;2018.

35. Shitaye D, Asrat D, Woldeamanuel Y, Worku B. Risk factors and etiology of neonatal sepsis in Tikur Anbessa University Hospital, Ethiopia. Ethiopian medical journal. 2010;48(1):11-21.

36. al. Ye. prevalence and risk factors of neonatal sepsis in Ethiopia 2008.

37. Mersha A, Worku T, Shibiru S, Bante A, Molla A, Seifu G, et al. Neonatal sepsis and associated factors among newborns in hospitals of Wolaita Sodo Town, Southern Ethiopia. Research and Reports in Neonatology. 2019;9:1.

38. Orwenyo GK. MATERNAL FACTORS PREDISPOSING TO EARLY-ONSET NEONATAL SEPSIS AT KENYATTA NATIONAL HOSPITAL MATERNITY UNIT. 2011.

39. S. M. NEONATAL SEPSIS, CYTOKINES AND THE ASSOCIATED FACTORS IN PATIENTS ADMITTED IN NAKURU COUNTY REFERRAL HOSPITAL, KENYA. 2010. 
40. Naulikha JM, Orindi OT, Amollo AS, Obonyo CO. Diagnosis and Management of Early-Onset Neonatal Sepsis (Eos) Among High-Risk Neonates in Kisii Teaching and Referral Hospital and Homabay County Referral Hospital, Western Kenya. 2018.

41. Laving A, Musoke R, Wasunna A, Revathi G. Neonatal bacterial meningitis at the newborn unit of Kenyatta National Hospital. East African medical journal. 2003;80(9):456-62.

42. Talbert AW, Mwaniki M, Mwarumba S, Newton CR, Berkley JA. Invasive bacterial infections in neonates and young infants born outside hospital admitted to a rural hospital in Kenya. The Pediatric infectious disease journal. 2010;29(10):945.

43. Le Geyt J, Hauck S. G272 Epidemiological trends of neonatal sepsis in a county referral hospital in central Kenya. BMJ Publishing Group Ltd; 2016.

44. Berkley JA, Lowe BS, Mwangi I, Williams T, Bauni E, Mwarumba S, et al. Bacteremia among children admitted to a rural hospital in Kenya. New England Journal of Medicine. 2005;352(1):39-47.

45. Kheir AE, Khair RA. Neonatal sepsis; prevalence and outcome in a tertiary neonatal unit in Sudan. Time Journals of Medical Sciences Report and Research. 2014;2(1):21-5.

46. Babiker W, Ahmed A, Babiker T, Ibrahim E, Almugadam B. Prevalence and Causes of Neonatal Sepsis in Soba University Hospital, Sudan. Med Microbiol Rep 1: 2. of. 2018;3:11-3.

47. Rijal P, Shrestha M. Analysis of Neonatal Respiratory Distress in Neonatal Intensive Care Unit at Nepal Medical College. Journal of Nepal Health Research Council. 2018;16(2):131-5.

48. Petwa KW, Callender-Carter, S.T., Ndungutse, D., and SamuelBiraro. Factors Influencing the Prevalence of Umbilical Cord Sepsis Among Newborn Babies at the China-Uganda Friendship Hospital Naguru. 2015.

49. Mugalu J, Nakakeeto M, Kiguli S, Kaddu-Mulindwa DH. Aetiology, risk factors and immediate outcome of bacteriologically confirmed neonatal septicaemia in Mulago hospital, Uganda. African health sciences. 2006;6(2):120-6.

50. Mobbs N, Ditai J, Abeso J, Faragher E, Carrol E, Gladstone M, et al. In search of a primary outcome for community-based newborn infection trials in Eastern Uganda: a nested cohort study within the BabyGel pilot trial. Pilot and feasibility studies. 2019;5(1):43.

51. Kiwanuka J, Bazira J, Mwanga J, Tumusiime D, Nyesigire E, Lwanga N, et al. The microbial spectrum of neonatal sepsis in Uganda: recovery of culturable bacteria in mother-infant pairs. PLoS One. 2013;8(8):e72775.

52. al Oe. prevalence and associated factors of neonatal sepsis in Uganda a cohort study. 2018.

53. Grace J Chan ACL, Abdullah H Baqui4, Jingwen Tan4and Robert E Black. RESEARCH ARTICLEOpen AccessPrevalence of early-onset neonatal infectionamong newborns of mothers with bacterialinfection or colonization: a systematic reviewand meta-analysis 2015.

54. Shruti MurthyID MAG, Vasudeva Guddattu ID, Leslie Edward, Simon Lewis NSN. Risk factors of neonatal sepsis in India: A systematic review and meta-analysis 2019. 
55. Chan GJ1 LA, Baqui AH, Tan J, Black RE. Risk of early-onset neonatal infection with maternal infection or colonization: a global systematic review and meta-analysis.2013.

56. Shruti MurthyID MAG, Vasudeva Guddattu ID, Leslie Edward. Risk factors of neonatal sepsis in India: A systematic review and meta-analysis. 2019.

\section{Figures}

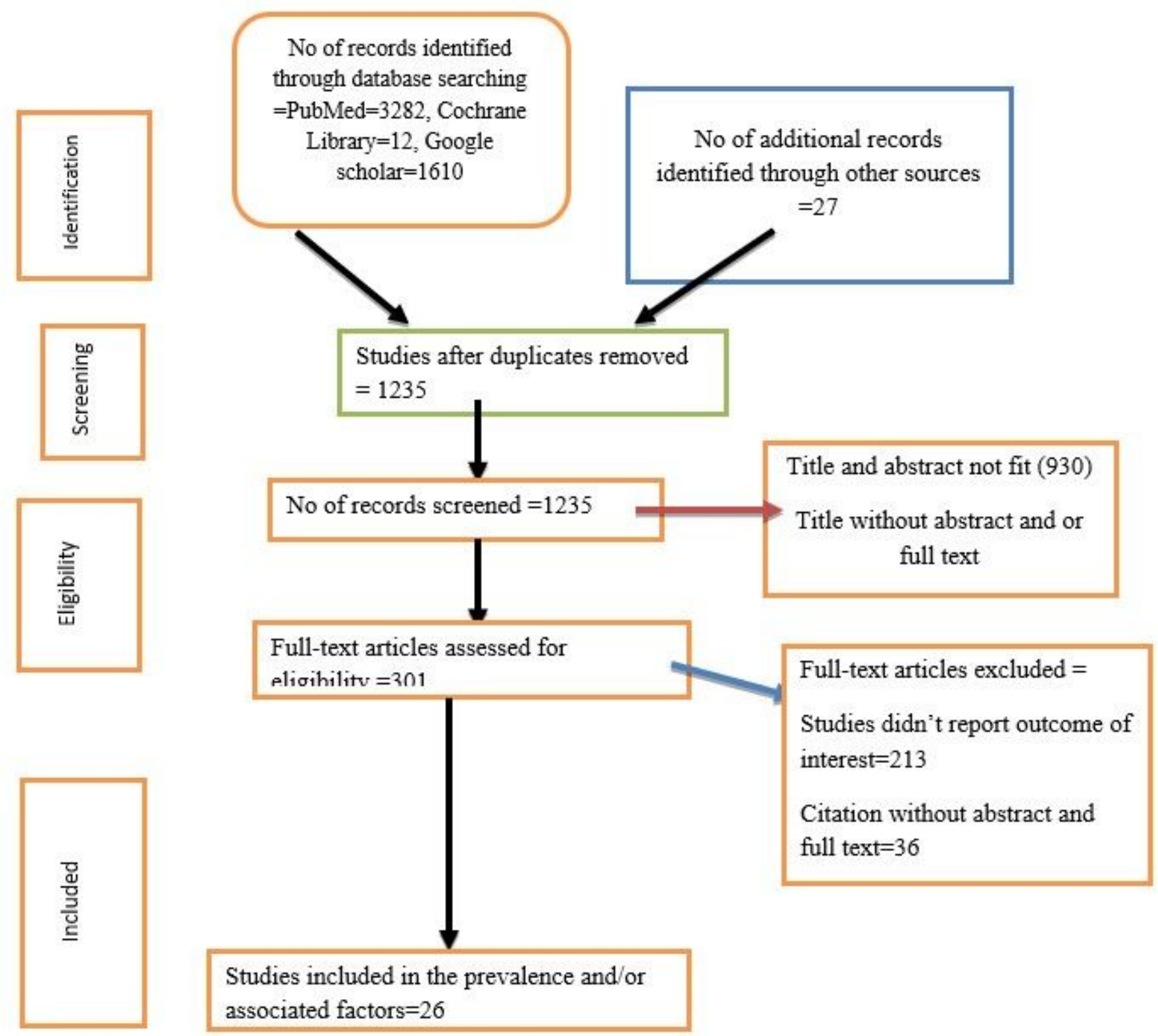

Figure 1 


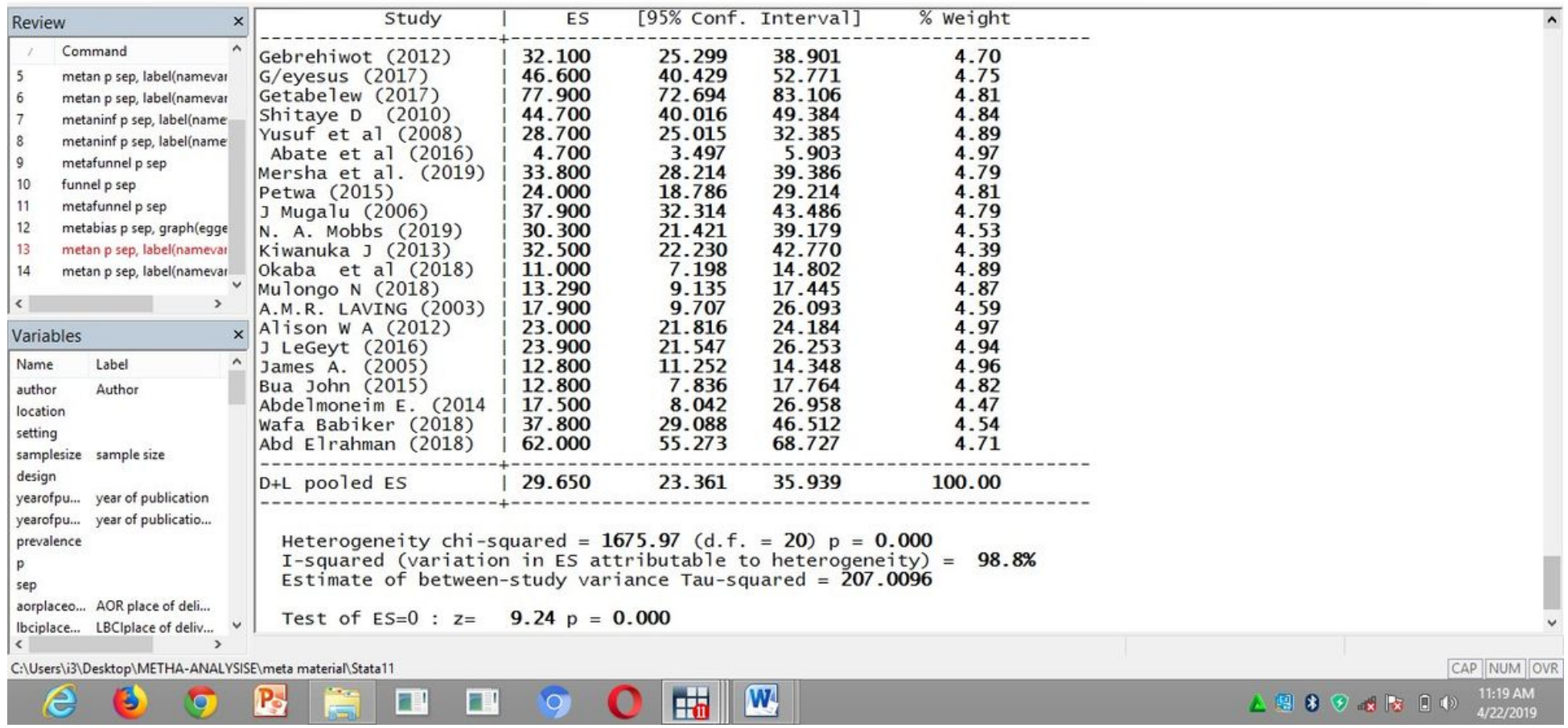

\section{Figure 2}

\section{Prevalence of neonatal sepsis}

낸.

File Edit Object Graph Tools Help

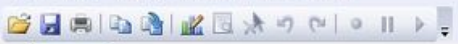

此 Graph

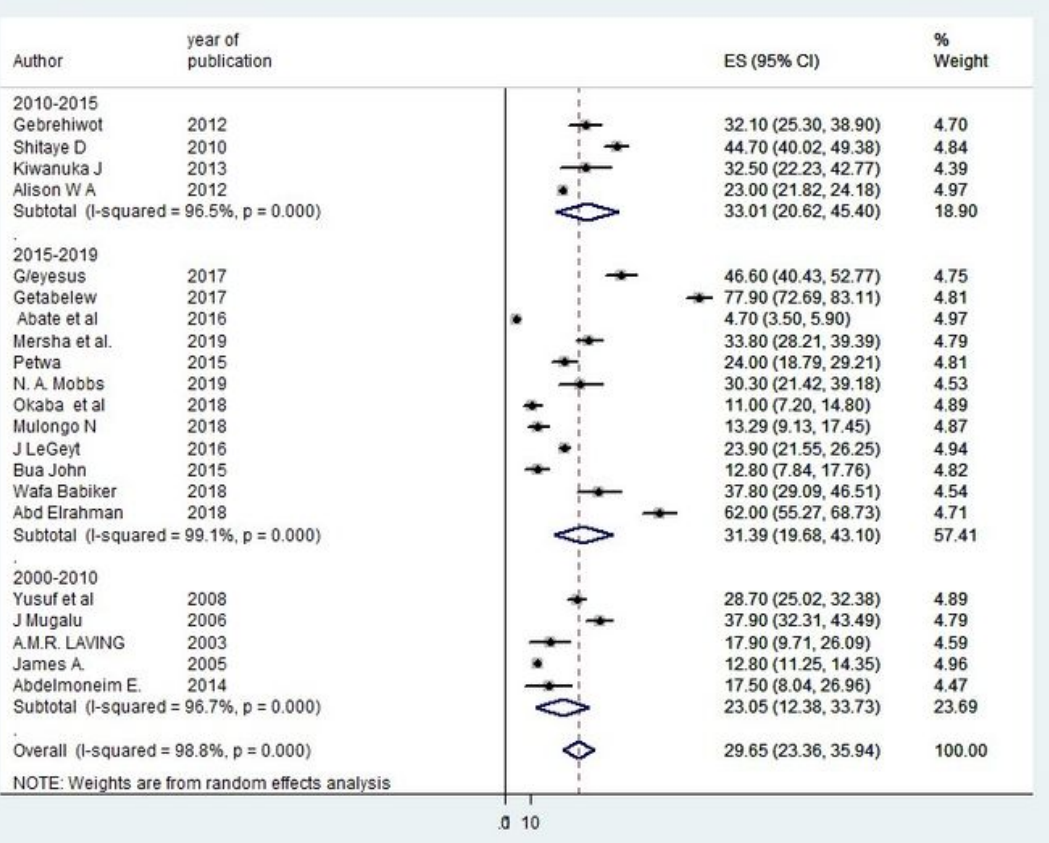


Figure 3

Subgroup analysis by year of publication

내

File Edit Object Graph Tools Help

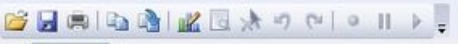

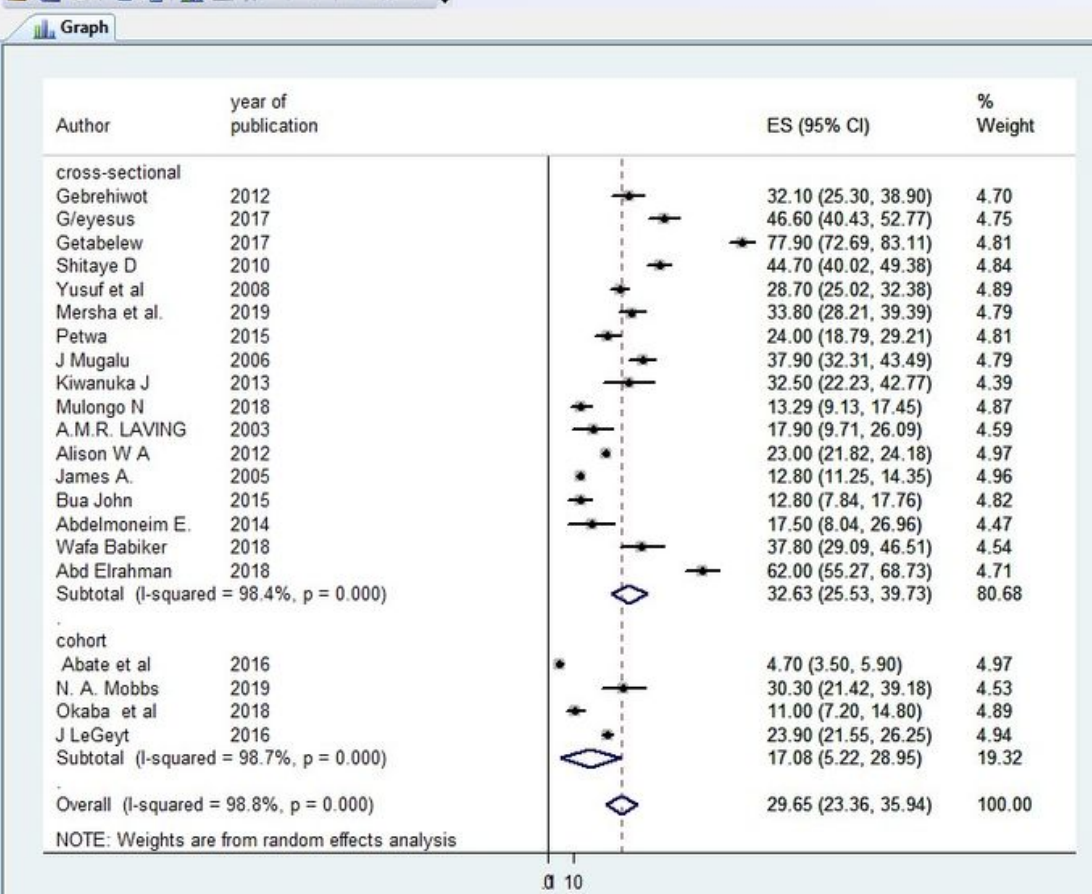

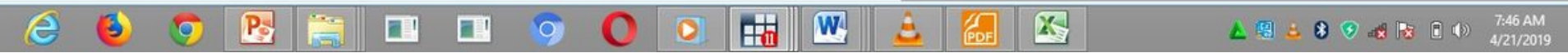

Figure 4

Subgroup analysis by study design 
File Edit Object Graph Tools Help

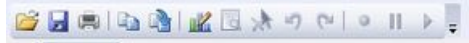

\begin{tabular}{|c|c|c|c|c|}
\hline Author & $\begin{array}{l}\text { year of } \\
\text { publication }\end{array}$ & & ES (95\% CI) & $\begin{array}{l}\text { क } \\
\text { Weight }\end{array}$ \\
\hline \multicolumn{5}{|l|}{ Ethiopis } \\
\hline $\begin{array}{l}\text { Gebrehiwot } \\
\text { GGevesus }\end{array}$ & $\begin{array}{l}2012 \\
2017\end{array}$ & & 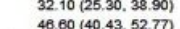 & $\begin{array}{r}4.70 \\
475\end{array}$ \\
\hline $\begin{array}{l}\text { G/eyesus } \\
\text { Getabulew }\end{array}$ & 2017 & & $\begin{array}{r}40.00(72.69 .83 .11) \\
\end{array}$ & $\begin{array}{l}.7 .75 \\
4.81\end{array}$ \\
\hline Shitaye D & 2010 & $\rightarrow$ & $44.70(40.02,49.38)$ & 4.84 \\
\hline Yusuf et al & 2008 & & $28.70(25.02 .32 .38)$ & 4.89 \\
\hline \multirow{2}{*}{\multicolumn{2}{|c|}{ 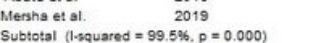 }} & & $4.70(3.50,5.90)$ & 4.97 \\
\hline & & & $\begin{array}{l}33.80(28.21 .1 .39 .39) \\
38.31(17.43 .59 .19)\end{array}$ & $\begin{array}{l}4.79 \\
33.74\end{array}$ \\
\hline \multicolumn{5}{|l|}{ Uganda } \\
\hline $\begin{array}{l}\text { Petwa } \\
\text { Petsol }\end{array}$ & 2015 & & $24.00(18.79 .29 .21)$ & 4.81 \\
\hline & & & $37.90(32.31 .43 .49)$ & 4.79 \\
\hline N. A. Mobbs & 2019 & & $30.30(21.42,39.18)$ & 4.53 \\
\hline Kiwanuka J & 2013 & & $32.50(22.23 .42 .77)$ & 4.39 \\
\hline \multirow{2}{*}{\multicolumn{2}{|c|}{ 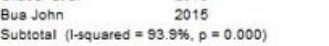 }} & & $11.00(7.20 .14 .80)$ & 4.89 \\
\hline & & & $\begin{array}{l}12.80(7.84,17.76) \\
24.40(14.91,33.90)\end{array}$ & $\begin{array}{l}4.82 \\
28.22\end{array}$ \\
\hline \multicolumn{5}{|l|}{ Kenya } \\
\hline Mulongo N & 2018 & & $13.29(9.13,17.45)$ & 4.87 \\
\hline A.M.R. LAVING & 2003 & & $17.90(9.71,28.09)$ & 4.59 \\
\hline Alison WA & 2012 & & $23.00(21.82 .24 .18)$ & 4.97 \\
\hline J LeGeyt & 2018 & & $23.90(21.55 .28 .25)$ & 4.94 \\
\hline \multirow{2}{*}{\multicolumn{2}{|c|}{ Subtotal (lesquared $=98.9 \%, p=0.000$ ) }} & & $12.80(11.25,14.35)$ & 4.96 \\
\hline & & $<$ & $18.28(12.84,23.91)$ & 24.32 \\
\hline Sudan & & & & \\
\hline Abdelmoneim E. & 2014 & & 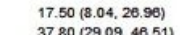 & 4.47 \\
\hline Wafa Babiker & 2018 & - & $37.80(29.09 .48 .51)$ & 4.54 \\
\hline $\begin{array}{l}\text { Abd Elranhman } \\
\text { Subtotal (1-square }\end{array}$ & $\begin{array}{l}2018 \\
.0 \%, p=0.000)\end{array}$ & $\Rightarrow$ & 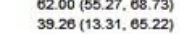 & $\begin{array}{l}4.71 \\
13.72\end{array}$ \\
\hline Overall (1-squarec & $\%, p=0.000\}$ & $\infty$ & $29.65(23.38 .35 .94)$ & 100.00 \\
\hline$T E$ Weights ar. & tandom eftects anslypis & & & \\
\hline
\end{tabular}

E (3) (9) $\mathrm{P}$ 与

\section{Figure 5}

\section{Subgroup analysis by country}

圈

File Edit Data Graphics Statistics User Window Help

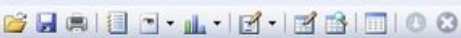

Command

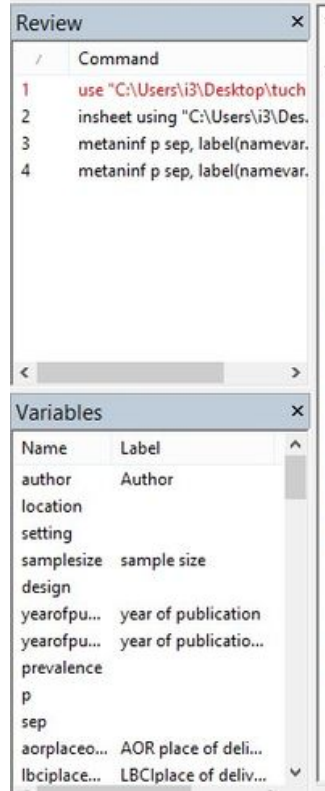

Stata/SE 11.0 - [Results]

\begin{tabular}{|c|c|c|c|}
\hline Study omitted & Estimate & {$[95 \%$ Conf. } & Interva1] \\
\hline 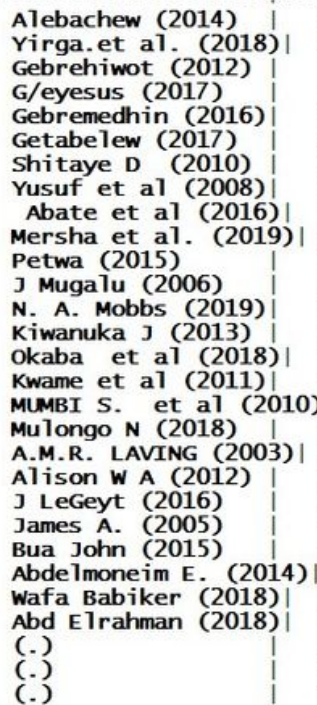 & $\begin{array}{l}29.650202 \\
29.650202 \\
29.529753 \\
28.801086 \\
29.650202 \\
27.150171 \\
28.877203 \\
29.701927 \\
30.940838 \\
29.441641 \\
29.937998 \\
29.234089 \\
29.619839 \\
29.519474 \\
30.611326 \\
29.650202 \\
\mid 29.650202 \\
30.490717 \\
30.216431 \\
30.026983 \\
29.958885 \\
30.54586 \\
30.506794 \\
\mid 30.220007 \\
29.262131 \\
28.042339 \\
29.650202 \\
29.650202 \\
29.650202\end{array}$ & $\begin{array}{l}23.36095 \\
23.36095 \\
23.077744 \\
22.465357 \\
23.36095 \\
21.688824 \\
22.588675 \\
23.181841 \\
24.964991 \\
22.995214 \\
23.434006 \\
22.82206 \\
23.172491 \\
23.082853 \\
24.064615 \\
23.36095 \\
23.36095 \\
23.948223 \\
23.749617 \\
22.572657 \\
23.229315 \\
23.454615 \\
23.99505 \\
23.763693 \\
22.836714 \\
21.875208 \\
23.36095 \\
23.36095 \\
23.36095\end{array}$ & $\begin{array}{l}35.939453 \\
35.939453 \\
35.981762 \\
35.136818 \\
35.939453 \\
32.611515 \\
35.165733 \\
36.222015 \\
36.916687 \\
35.888065 \\
36.44199 \\
35.646118 \\
36.067188 \\
35.956097 \\
37.158035 \\
35.939453 \\
35.939453 \\
37.033211 \\
36.683247 \\
37.481312 \\
36.688454 \\
37.637108 \\
37.018539 \\
36.676319 \\
35.68755 \\
34.209473 \\
35.939453 \\
35.939453 \\
35.939453\end{array}$ \\
\hline
\end{tabular}

C:IUsersli3\Desktop IMETHA-ANALYSISEImeta material Stata11

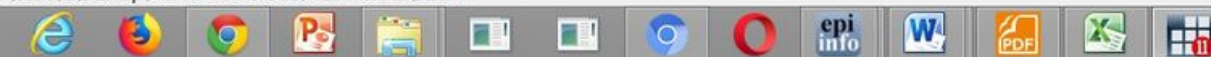


Figure 6

Sensitivity analysis

\section{圈}

File Edit Data Graphics Statistics User Window Help

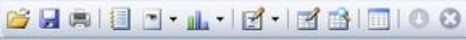

Command

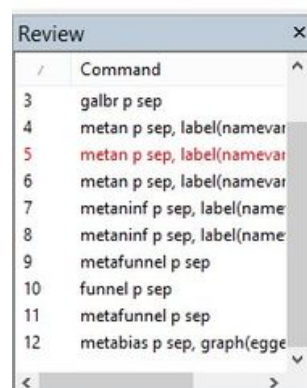

Variables $\quad x$

Name Label

author Author

location

setting

samplesize sample size

design

yearofpu... year of publication

yearofpu... year of publicatio. prevalence

$\mathrm{p}$

aorplaceo... AOR place of deli...

Ibciplace... LBCIplace of deliv..., $\checkmark \mid$.

C:IUsersli32DesktopIMETHA-ANALYSISEImeta material Stata11

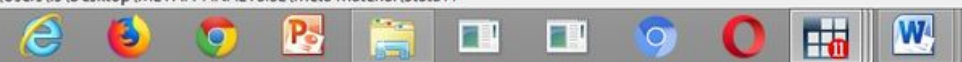

funnel p sep

- metafunnel p sep

Note: default data input format (theta, se_theta) assumed.

- metabias p sep, graph(egger)

Note: default data input format (theta, se_theta) assumed.

Tests for Publication Bias

Begg's Test

adj. Kenda 11 's Score $(P-Q)=$ Std. Dev. of Score = Number of Studies $=$

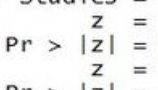

19

33.10 (corrected for ties)

0.57

0.566

0.54 (continuity corrected)

0.587 (continuity corrected)

Egger's test

\begin{tabular}{r|rrrrrr}
\hline Std_Eff & Coef. & Std. Err. & $t$ & $P>|t|$ & [95\% Conf. Interva1] \\
\hline slope & $\mathbf{9 . 3 4 4 9 3 1}$ & $\mathbf{3 . 9 6 9 1 7 2}$ & $\mathbf{2 . 3 5}$ & $\mathbf{0 . 0 2 9}$ & $\mathbf{1 . 0 3 7 3 5 9}$ & $\mathbf{1 7 . 6 5 2 5}$ \\
bias & $\mathbf{7 . 7 8 7 4 3 7}$ & 2.715326 & $\mathbf{2 . 8 7}$ & $\mathbf{0 . 0 1 0}$ & $\mathbf{2 . 1 0 4 1 9 5}$ & $\mathbf{1 3 . 4 7 0 6 8}$
\end{tabular}

\section{Figure 7}

\section{Publication bias}




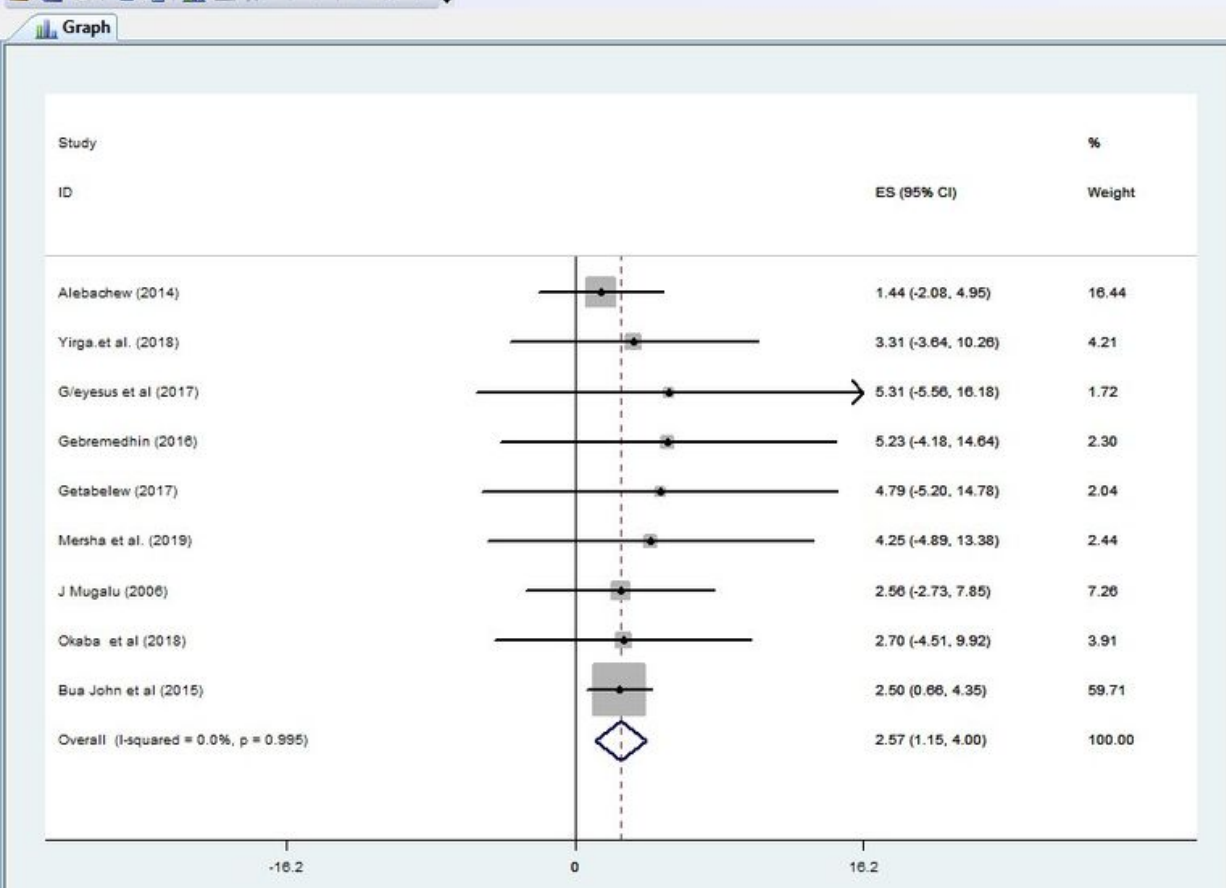

(e) (3) 9 P

\section{Figure 8}

The pooled effect of place of birth

圈

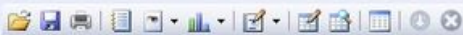

Command

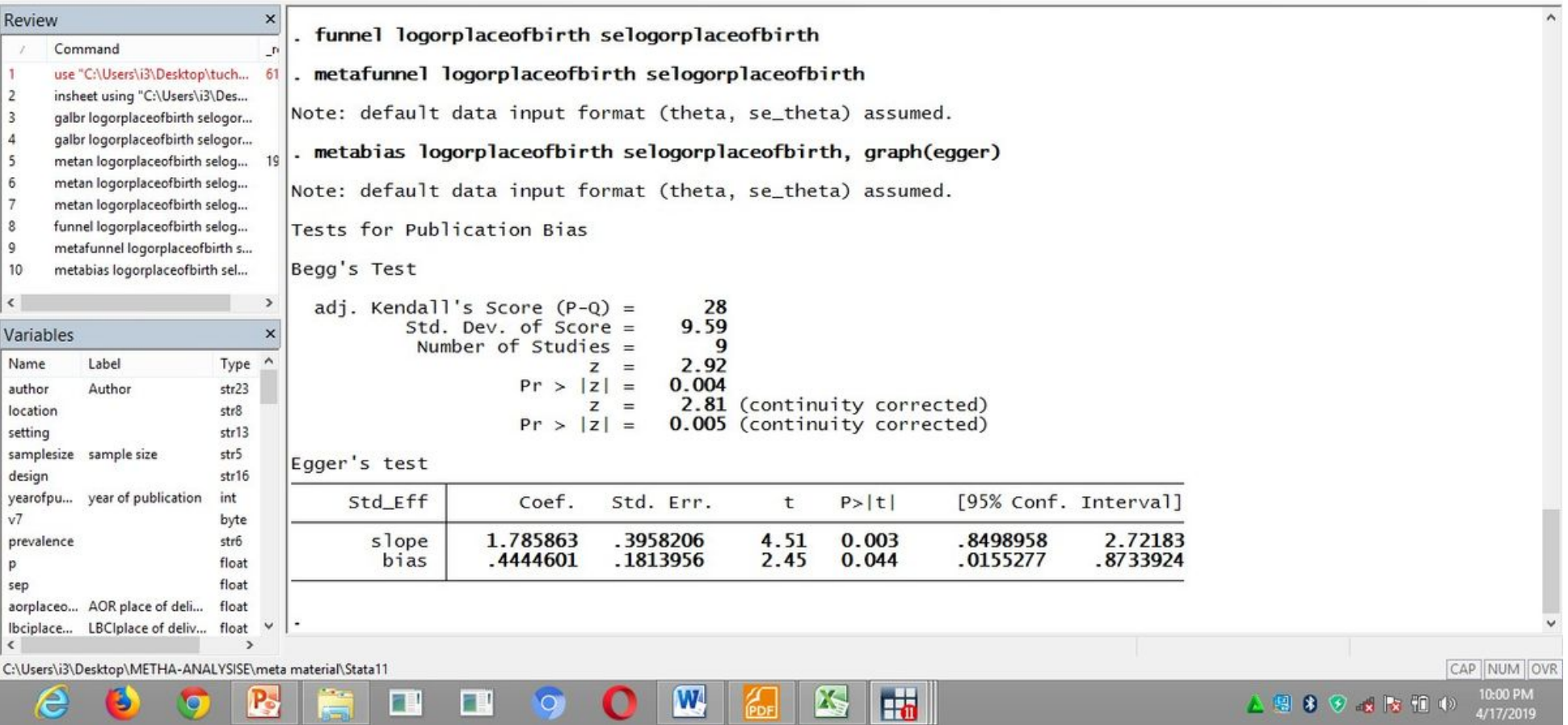


Figure 9

Publication bias for the place of birth

圈

File Edit Data Graphics Statistics User Window Help

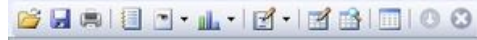

Command

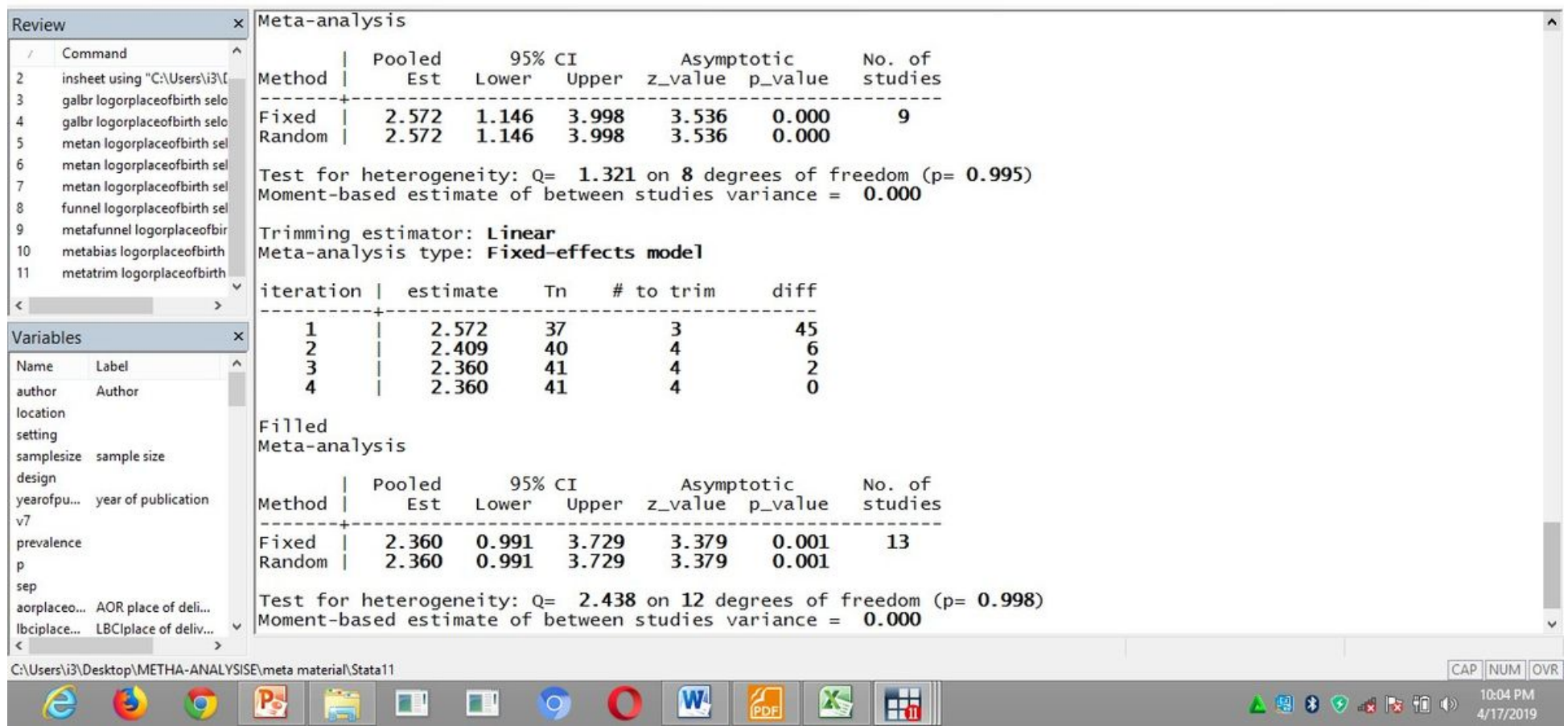

\section{Figure 10}

Trim and fill analysis place of birth 


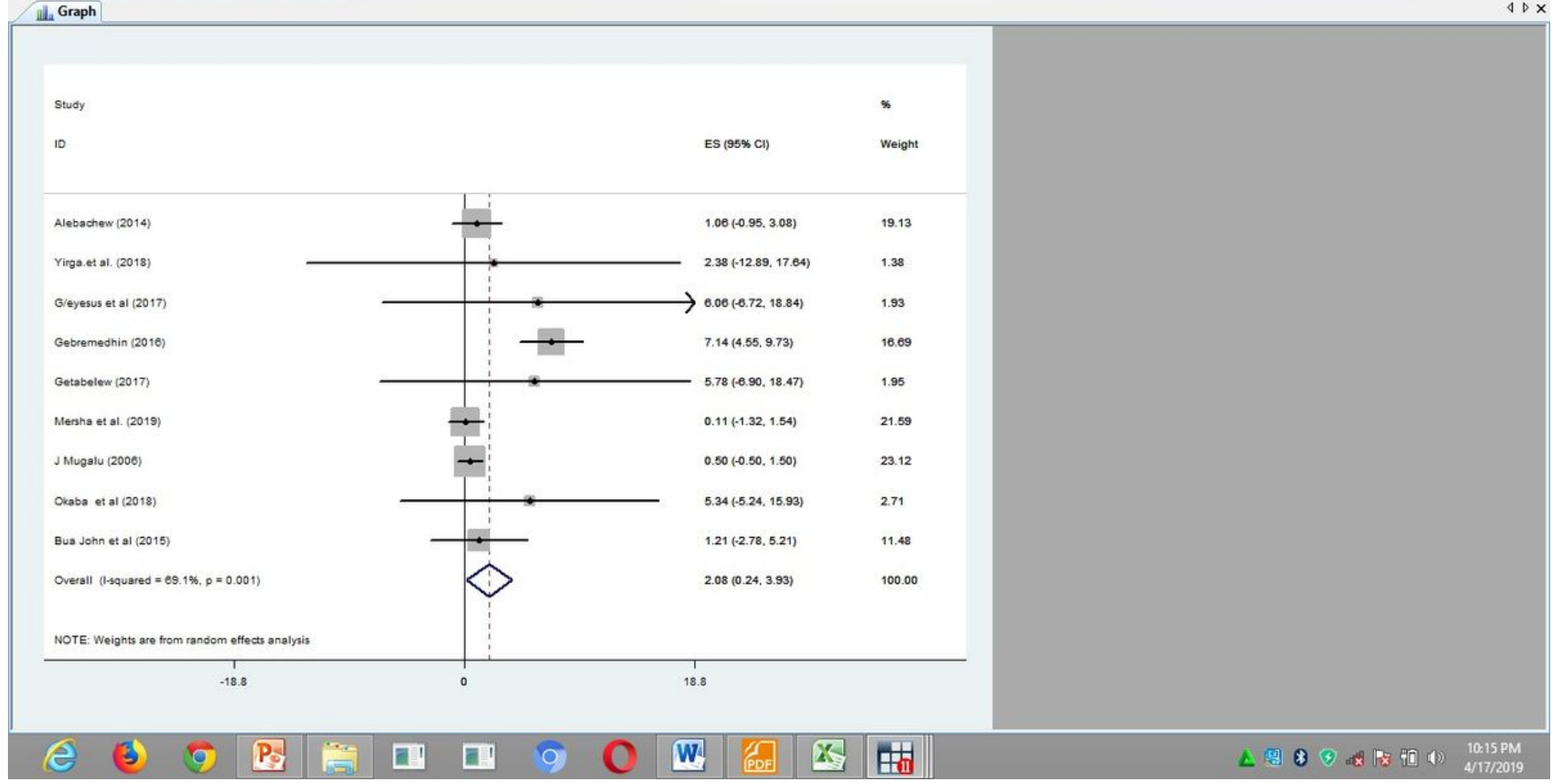

\section{Figure 11}

\section{The pooled estimate of UTI}

圈

File Edit Data Graphics Statistics User Window Help

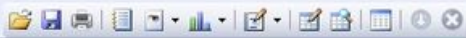

\section{Command}

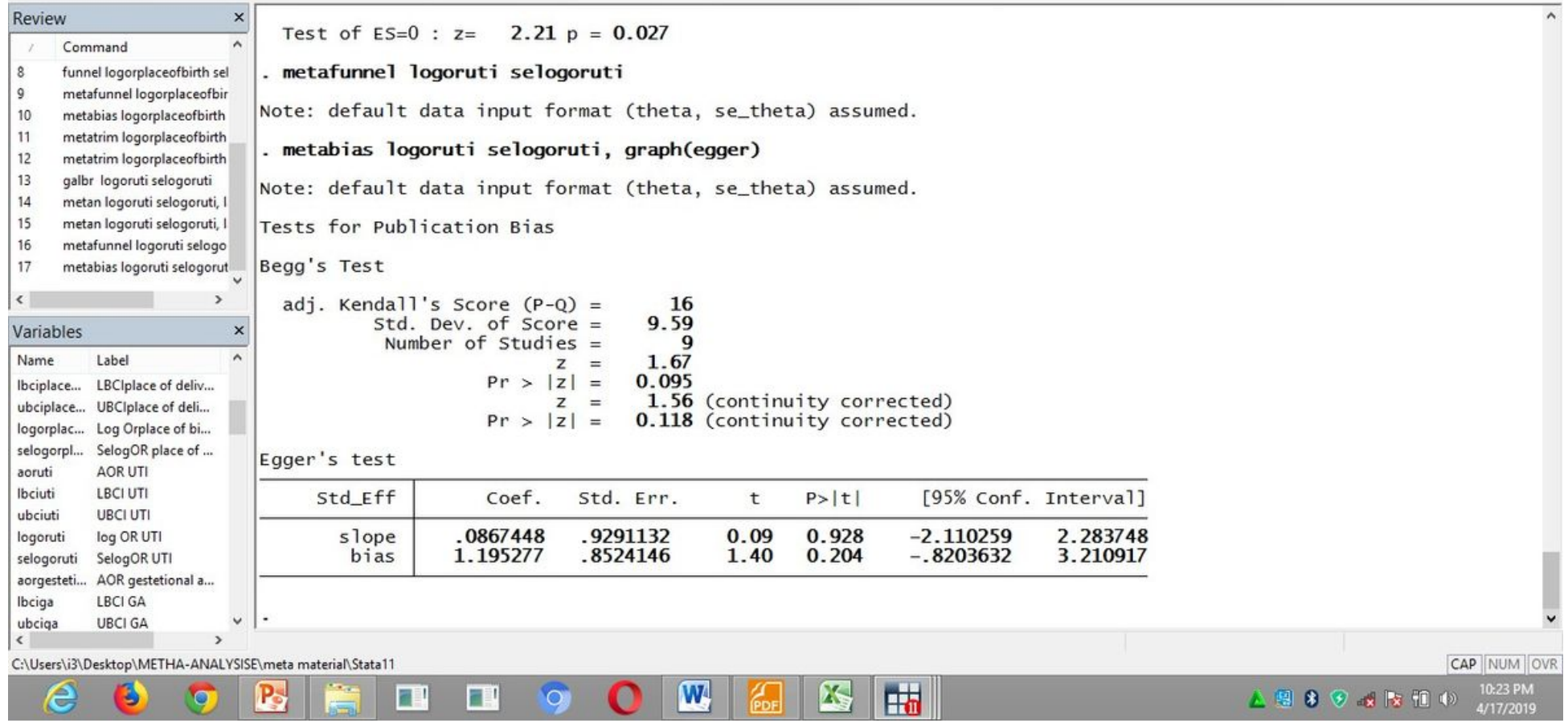


Figure 12

publication bias of gestational age (preterm)

all

Stata Graph - Graph

File Edit Object Graph Tools Help

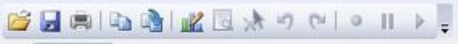

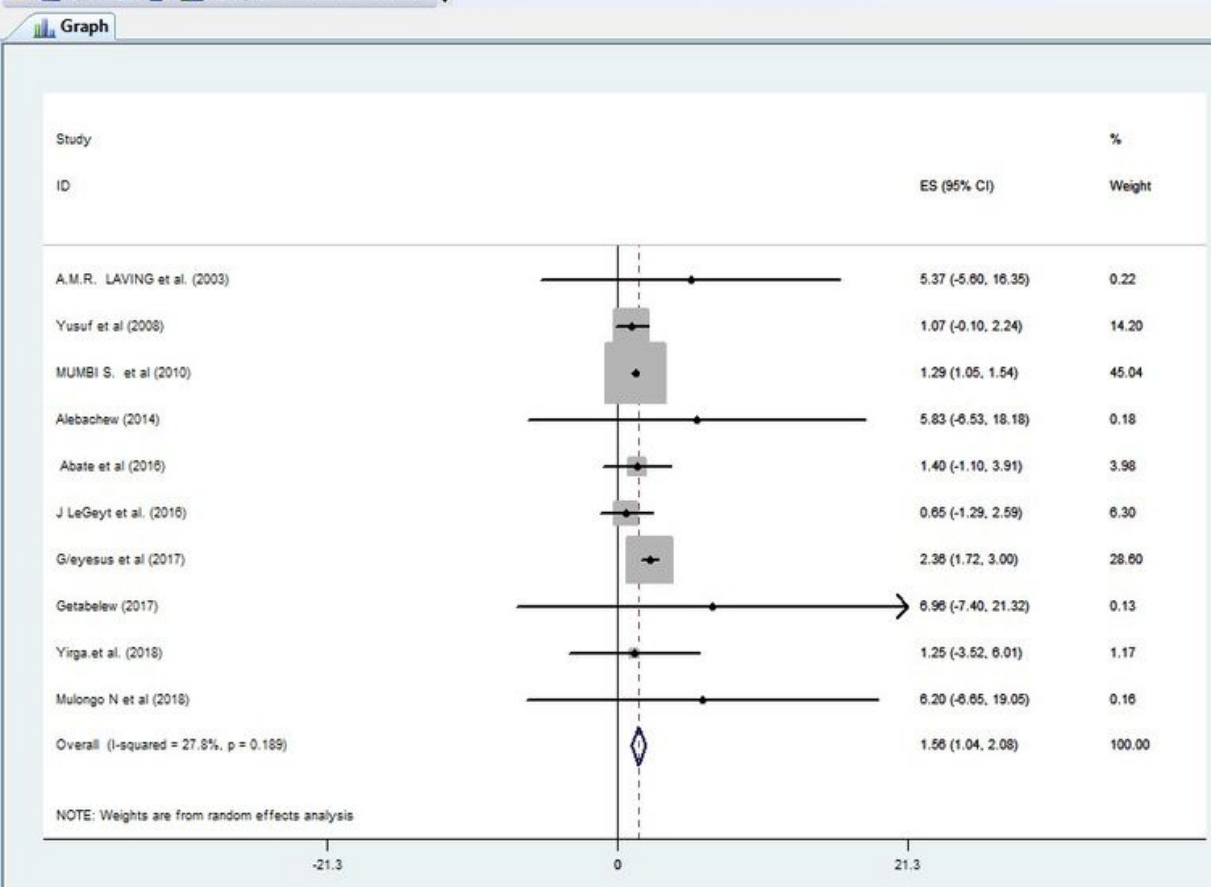

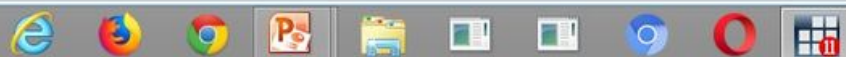

Figure 13

Preterm pooled estimate preterm 


\begin{tabular}{|c|c|}
\hline \multicolumn{2}{|c|}{ Review } \\
\hline ' & Command \\
\hline 14 & metafunnel logorprom selogo... \\
\hline 15 & metabias logorprom selogorpr... \\
\hline 16 & metatrim logorprom selogorpr... \\
\hline 17 & galbr logormodeofdelivery sel... \\
\hline 18 & galbr logorbirthaspyxia selog... \\
\hline 19 & galbr logorpreterm selogorpret... \\
\hline 20 & metan logorpreterm selogorpr... \\
\hline 21 & metan logorpreterm selogorpr... \\
\hline 22 & metabias logorpreterm selogo... \\
\hline 23 & metabias logorpreterm selogo... \\
\hline
\end{tabular}

Variables $\quad x$

Name Label Type $\wedge$

ubciprete... UBCI preterm

logorpret... log OR preterm

selogorpr... SelogOR preterm

selogorp.
$v 64$
$v 65$

v65

$v 66$
$v 67$

v68

v69

v71

v 72

C:IUsersli3'DesktopIMETHA-ANALYSISElmeta materialSStata11

\begin{tabular}{r|rrcrrr}
\hline Std_Eff & Coef. & Std. Err. & t & P $>|t|$ & [95\% Conf. Interva1] \\
\hline slope & $\mathbf{1 . 3 1 2 6 6 7}$ & $\mathbf{. 1 5 7 9 7 8 5}$ & $\mathbf{8 . 3 1}$ & $\mathbf{0 . 0 0 0}$ & $\mathbf{. 9 4 8 3 6 7 9}$ & $\mathbf{1 . 6 7 6 9 6 6}$ \\
bias & $\mathbf{. 4 9 8 7 1 4 2}$ & $\mathbf{. 4 4 1 3 7 8 3}$ & $\mathbf{1 . 1 3}$ & $\mathbf{0 . 2 9 1}$ & $-\mathbf{5 1 9 1 0 6 1}$ & $\mathbf{1 . 5 1 6 5 3 4}$ \\
\hline
\end{tabular}

- metabias logorpreterm selogorpreterm, graph(egger)

Note: default data input format (theta, se_theta) assumed.

Tests for Publication Bias

Begg's Test Number of Studies $=$

Egger's test adj. Kenda 11's Score $(P-Q)=$ Std. Dev. of Score $=$

$$
\operatorname{Pr}>|z|=
$$

1.97 (continuity corrected)

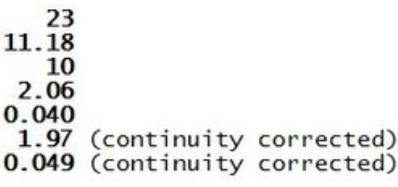

\begin{tabular}{r|rcccrr}
\hline Std_Eff & Coef. & Std. Err. & $\mathrm{t}$ & $\mathrm{P}>|\mathrm{t}|$ & [95\% Conf. Interva1] \\
\hline slope & $\mathbf{1 . 3 1 2 6 6 7}$ & $\mathbf{. 1 5 7 9 7 8 5}$ & $\mathbf{8 . 3 1}$ & $\mathbf{0 . 0 0 0}$ & $\mathbf{. 9 4 8 3 6 7 9}$ & $\mathbf{1 . 6 7 6 9 6 6}$ \\
bias & $\mathbf{. 4 9 8 7 1 4 2}$ & $\mathbf{. 4 4 1 3 7 8 3}$ & $\mathbf{1 . 1 3}$ & $\mathbf{0 . 2 9 1}$ & $\mathbf{- . 5 1 9 1 0 6 1}$ & $\mathbf{1 . 5 1 6 5 3 4}$
\end{tabular}

\section{(e) (3) 9 P}

\section{Figure 14}

\section{Publication bias preterm}

圈

File Edit Data Graphics Statistics User Window Help

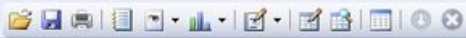

\section{Command}

\section{Review \\ , Command \\ 5 metabias logorprom selogorpr... \\ 17 metatrim logorprom selogorpr... \\ galbr logormodeofdelivery sel... galbr logorbirthaspyxia selog... galbr logorpreterm selogorpret... metan logorpreterm selogorpr... metan logorpreterm selogorpr... \\ metabias logorpreterm selogo.. \\ metabias logorpreterm selogo... \\ metatrim logorpreterm selogor...

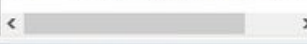

Variables

Name Label

ubciprete... UBCI preterm

logorpret... log OR preterm

selogorpr... SelogOR preterm

v64

v65

v66

468

v69

v70

$v 71$

v72

C: UsersLi3\DesktopIMETHA-ANALYSISEImeta material/Stata11

\begin{tabular}{|c|c|c|c|c|c|c|}
\hline \multicolumn{7}{|c|}{ Meta-analysis } \\
\hline \multirow[b]{2}{*}{ Method } & \multirow{2}{*}{$\begin{array}{r}\text { Pooled } \\
\text { Est }\end{array}$} & \multicolumn{2}{|c|}{$95 \%$ CI } & \multicolumn{2}{|c|}{ Asymptotic } & \multirow{2}{*}{$\begin{array}{l}\text { No. of } \\
\text { studies }\end{array}$} \\
\hline & & Lower & Upper & z_value & p_value & \\
\hline $\begin{array}{l}\text { Fixed } \\
\text { Random }\end{array}$ & $\begin{array}{l}1.412 \\
1.563\end{array}$ & $\begin{array}{l}1.190 \\
1.042\end{array}$ & $\begin{array}{l}1.634 \\
2.084\end{array}$ & $\begin{array}{r}12.477 \\
5.878\end{array}$ & $\begin{array}{l}0.000 \\
0.000\end{array}$ & 10 \\
\hline
\end{tabular}

Filled
Test for heterogeneity: $Q=12.457$ on 9 degrees of freedom $(p=0.189)$

Moment-based estimate of between studies variance $=\mathbf{0 . 1 4 1}$

Trimming estimator: Linear

Meta-analys is type: Random-effects model

iteration | estimate Tn \# to trim diff

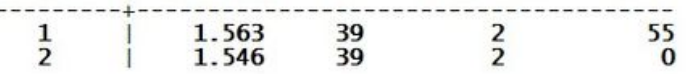

Meta-analysis (exponential form)

| Pooled $95 \%$ CI Asymptotic No. of Method Est Lower Upper z_value p_value studies

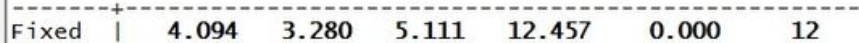

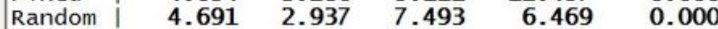

Test for heterogeneity: $Q=13.452$ on 11 degrees of freedom $(p=0.265)$

Moment-based estimate of between studies variance $=\mathbf{0 . 1 0 0}$

(8) 0 P 
Figure 15

Trim and fill preterm

至

File Edit Object Graph Tools Help

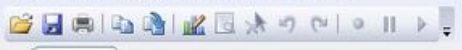

\begin{tabular}{|c|c|c|}
\hline Llaph & & \\
\hline Study & & $\%$ \\
\hline 10 & ES (95\% Cl) & Weight \\
\hline J Mugalu (2006) & $0.34(-0.80,1.49)$ & 38.01 \\
\hline Alebachew (2014) & 5.05 (-5.5s, 15.05) & 7.03 \\
\hline Gebremedhin (2016) & $7.43(3.43 .11 .43)$ & 24.14 \\
\hline Getabelew (2017) & $1.83(-1.65,4.90)$ & 27.39 \\
\hline Yigg.et al. (2018) & $9.48(-9.18,28.14)$ & 2.85 \\
\hline Okaba et al (2018) & $=10.87(-11.87,33.61)$ & 1.97 \\
\hline Overal (1-squared $=62.7 \%, p=0.020$ ) & $3.23(-0.05,6.51)$ & 100.00 \\
\hline NOTE: Weights are from random effeets analysis & & \\
\hline .33 .6 & & \\
\hline
\end{tabular}

(e) (3) 9 P

Figure 16

Pooled estimate of prolonged labor 


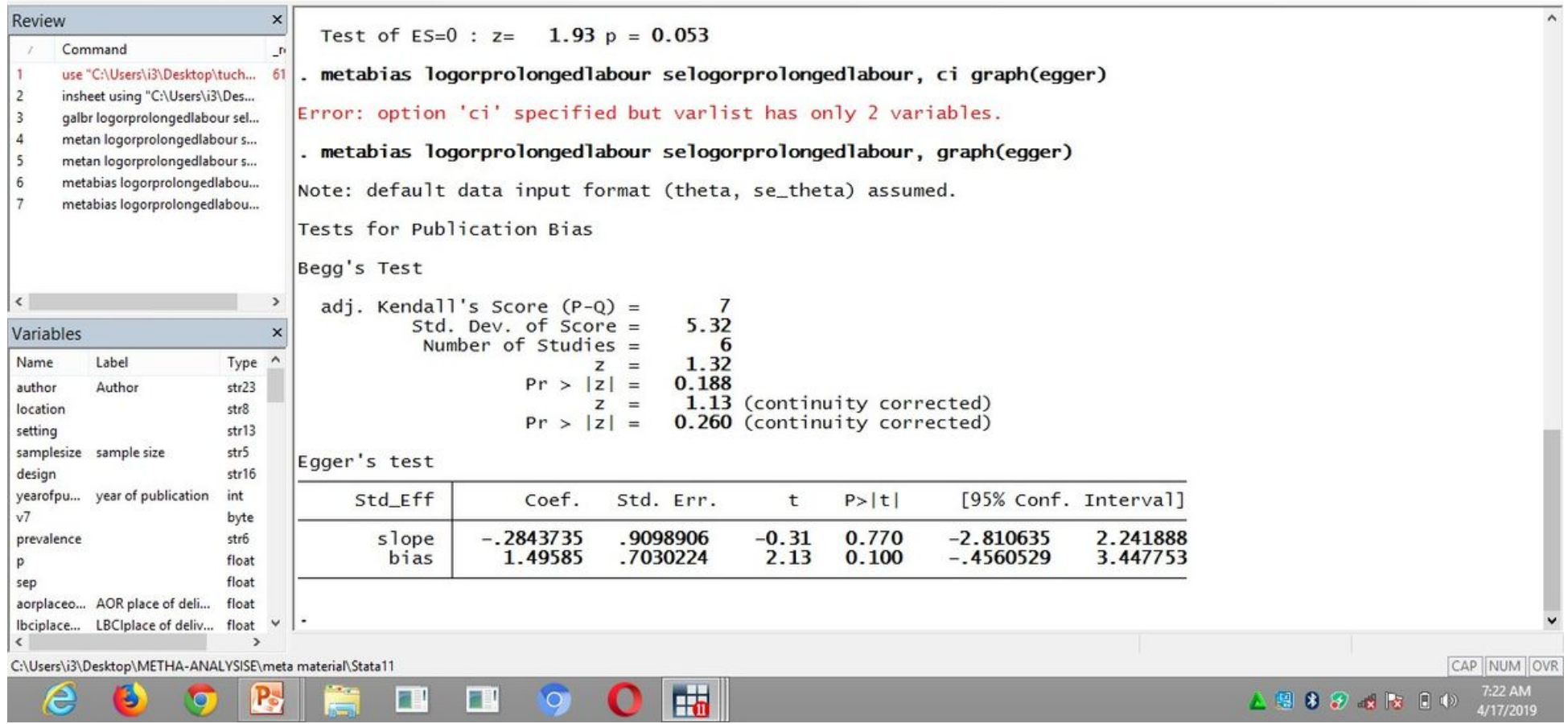

\section{Figure 17}

\section{test of publication bias prolonged labor}

illu

File Edit Object Graph Tools Help

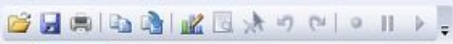

$$
\text { Illaph }
$$

\begin{tabular}{|c|c|c|}
\hline \multirow{2}{*}{$\begin{array}{l}\text { Study } \\
\text { 10 }\end{array}$} & \multirow[b]{2}{*}{ ES $(95 \% \mathrm{Cl})$} & \multirow{2}{*}{$\begin{array}{l}\% \\
\text { Weigh }\end{array}$} \\
\hline & & \\
\hline A.M.R. LAVING et 21. (2003) & $3.56(-3.78,10.90)$ & 3.38 \\
\hline J Mugalu (2008) & $0.44(-0.03,1.51)$ & 28.81 \\
\hline MUMai S. et al (2010) & $0.00(-0.37,18.49)$ & 1.25 \\
\hline Kuame et al (2011) & $1.92(-1.53,5.37)$ & 11.33 \\
\hline Gebremesanin (2016) & $3.39(2.33 .4 .45)$ & 28.91 \\
\hline Qieyesus et al (2017) & $=10.17(-11,14,31.47)$ & 0.44 \\
\hline Getabelew (2017) & $1.25(-1.71,4.20)$ & 13.80 \\
\hline Yirgs.et al. (2018) & $2.34(-19.76,24.44)$ & 0.41 \\
\hline Okaba et al (2018) & $7.37(-6.76 .21 .50)$ & 0.98 \\
\hline Mulompo N et al (2018) & $7.13(-7.47 .21 .72)$ & 0.92 \\
\hline Mersha et al. (2019) & $0.02(-3.21,4.45)$ & 9.80 \\
\hline Overal (1-squares $=43.2 \%, p=0.002$ ) & $1.95(0.53,3.30)$ & 100.00 \\
\hline NOTE: Weights are from random effects anaysis & & \\
\hline $\begin{array}{l}1 \\
-31.5\end{array}$ & & \\
\hline
\end{tabular}


Figure 18

pooled estimate PROM

图

File Edit Data Graphics Statistics User Window Help

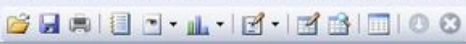

Command

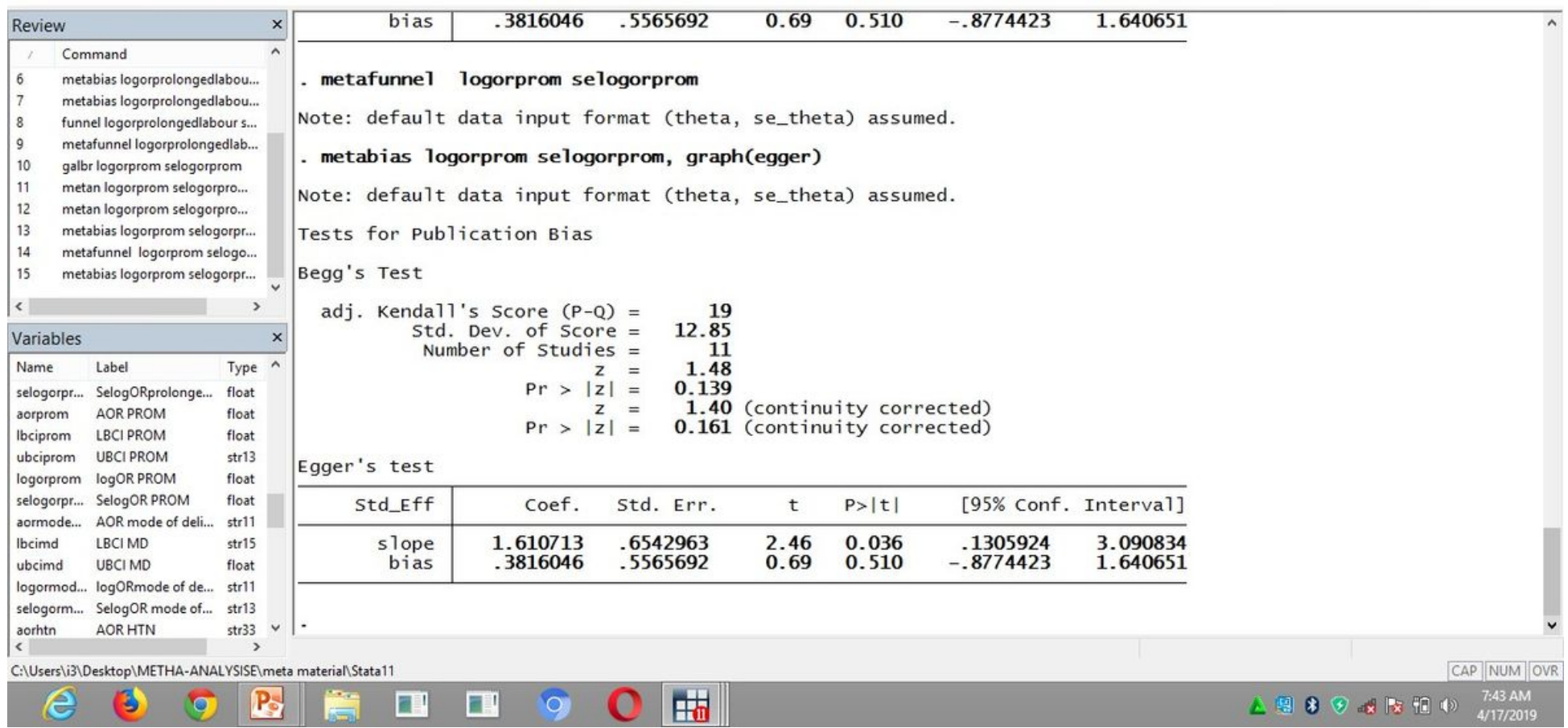

\section{Figure 19}

\section{Publication bias PROM}

